RUUT VEENHOVEN AND PIET OUWENEEL

\author{
LIVABILITY OF THE WELFARE-STATE \\ Appreciation-of-life and length-of-life in nations varying in \\ state-welfare-effort
}

(Accepted March 4, 1995)

\begin{abstract}
One issue in the debate on the welfare-state is whether state-care renders society more livable or not. The positive view is that people flourish in the welfare-state, the negative view is that people thrive better without. This article approaches the dispute empirically, by comparing livability of nations that differ in state-welfare-effort. The livability of nations is measured by the degree to which its citizens live long and happily. State-welfare-effect is measured by the scope of welfare-laws and the size of state-welfare-expenditures.

Data on average appreciation-of-life around 1980 are available for 28 nations; mostly rich ones. Appreciation-of-life appears somewhat greater in the nations that provide most state-welfare. However, that difference is entirely due to parallel differences in economic affuence. Data on change in life-satisfaction between 1950 and 1980 are available for only 10 nations, all rich ones. Life-satisfaction. did not increase more in the nations where state-welfare expanded most.

Data on length-of-life in 1980 are available for 97 nations, of which 28 rich ones. Life-expectancy appears to be greater in the nations that provide most statewelfare, but again the difference disappears when income per head is controlled. Data on change in life-expectancy 1965-1985 are available for 35 nations. Gains in life-expectancy appear not greater in the nations were state-welfare expanded most.

It is concluded that state involvement in welfare provision does not create a more livable society. Apparently, non-state welfare works out equally well in present day conditions.
\end{abstract}

\title{
INTRODUCTION
}

The welfare state has been under debate since it emerged. The debate intensified during the last decade, when a slowdown in economic growth forced cuts in government expenditures. The focus of the discussion is on technical issues, such as how much government expenditure the market-economy can pay and whether state-welfare services can be produced more efficiently. On the background there 
is also a more fundamental discussion on the desirability of the welfare-state as such. There are several issues in that discussion: one point of controversy is whether welfare-states really succeed in creating more equality, or rather conceal existing cleavages and create new ones. Another issue is whether the welfare-state brings out the best in people, or rather impairs initiative and solidarity in the long run. This point links up with the question about freedom in the welfare-state. Doesn't state-care make citizens irresponsible and dependent, and won't that foster a tendency of Father-State to develop into a Big-Brother? A third point of debate is whether state corporations are efficient producers of welfare services. It is argued that state-monopoly and -bureaucracy provide poor products. Much of these discussions lead to the question whether the welfare-state makes society more 'livable' or not. This article focuses on that latter issue.

\section{Claimed Livability of the Welfare-State}

Opinions differ widely on this matter. ${ }^{1}$ Roughly there are two points of view.

\section{The positive view}

The welfare-state is a superb social invention that provides a better quality of life to more people than any society did ever before. The welfare-state not only banned poverty, but realized an unprecedented standard of living for the masses. It greatly reduces the pain of social inequality and protects the citizens effectively against the whims of capitalistic market economy. By granting basic needs for subsistence, security and respect, the welfare-state frees the way for the gratification of higher needs that yield more satisfaction. As a result people live well in welfare-states. Curtailment on state-welfare will make life harsh and uncertain again. The less the state concerns itself with the welfare of citizens, the less habitable society will be. In modern individualized society, the welfare-state is in fact an indispensable institution.

\section{The negative view}

State-care from the cradle to the grave may seem comfortable, but is not really satisfying. It makes people dependent and thereby frustrates basic needs for autonomy, challenge and selfrespect. Clients 
of the welfare state are confronted with an alienating bureaucracy and get stuck in poverty traps. Unintended undermining of family and church creates moral disruption and weakens intimate support. In the long run welfare-states not even guarantee a decent income for everybody, because it ruins the economy. This all makes citizens basically insecure and lonely. Other institutions than the state can produce better services for the same money with less negative sideeffects. Hence cuts on state-welfare will not really hurt; at least not in the long run. The more the state meddles in citizens lives, the less livable society will become.

\section{Check on Livability}

Rather than theorize about possible costs and benefits of statewelfare, we can try to decide the discussion empirically. We can do so by comparing the livability of nations that differ in statewelfare-effort. What is then 'livability"?

The concept of livability refers to the degree to which provisions and requirements of a society fit with the needs and capacities of its members. A society is unlivable if it fails to gratify basic human needs. A society is also unlivable if it demands the impossible. See Veenhoven (1993) for a more detailed discussion of the concept.

Livability as such cannot be measured. We can hardly observe all individual 'needs' and 'capacities', and certainly not their ' $f i t$ ' with societal 'provisions' and 'requirements'. However, we can estimate the livability of nations indirectly. There are two approaches: 1) estimation on the basis of living conditions in the nation and 2) estimation on the basis of thriving of the citizens.

\section{Presumed livability}

Livability of nations is mostly estimated by the presence of livingconditions that are deemed likely to fit with the needs and capacities of most citizens. Such conditions are typically: high economic development, effective protection of human rights, political democracy, good health care and education for everybody. Sometimes, an active welfare-state is also mentioned in this context. In this approach, livability is measured by the quality of societal provisions. In other words: by societal 'input'. 
There are two problems with this approach. One problem is in the assumption that these conditions suit human nature; most of its existence humanity has done without. A second problem is the assumption that more of these conditions denotes better livability. Even if one accepts that humans thrive well in affluence and democracy, it is still questionable whether more of this makes them thrive better.

To underscore the speculative character of this approach we refer to it as 'presumed livability'.

\section{Apparent livability}

An other way to estimate livability of a country is to assess how well people flourish in it. The focus is then on societal 'output'. In this view, a society where people pine away cannot be livable, even if its living-conditions are presumed to be good.

Human thriving can be assessed in two ways. Like other biological organisms, it manifests in the first place in good health and ultimately in the length of life. Because humans are conscious beings, it also displays in their appreciation of life. If citizens in a country are happy, that country must be reasonable livable. Together these criteria merge in the situation fairy tales end in: a long and happy life.

We refer to this estimate of livability as 'apparent' livability.

In the present discussion about the merits of the welfare-state, the conception of 'presumed' livability is problematic.

One problem is that a high degree of state-welfare is often among the conditions deemed required for a good life. For example, statewelfare is one of the seven criteria in Naroll's (1982) 'Quality of Life Index' (operationalisation of his 'Brotherhood' criterion). This leads into tautology.

Even if we remove state-welfare from the list of beneficial livingconditions, there is still some tautology in the use of conceptions of presumed livability in this debate. The question that remains is then whether state-welfare is conducive to other conditions deemed desirable, such as economic growth, social equality and respect for human rights. For some conditions that is almost implied. Rather evidently, welfare-states provide more social equality, because their main activity is redistribution. If one considers income security as a 
human right, welfare-states are by implication quite livable as well, because they guarantee every citizen a minimum income.

A further problem is that this approach does not enable an overall judgement. It leads into appraisals of specific effects of state-welfare, but does not embody a way to assess the total of effects. Suppose that we could establish that state-welfare is slightly detrimental to economic growth (in some conditions, at some levels), but that is tends to produce more social equality of various kinds. Such observations would not allow a conclusion about the livability of the welfare-state, because it is not established that economic growth is more crucial than social equality. If no clear value priorities are established, conclusions about more or less livability are possible only if all effects are in the same direction; e.g., if state-welfare works out positively on everything deemed beneficial. This is typically not the case. The very problem in the discussion of the welfare-state is to strike the balance of its contradictory effects.

In fact, speaking of livability in the sense of 'presumed' livability does not clarify the discussion. It rather obscures the issue by suggesting a common criterion that does not exist.

For these reasons we opt for considering 'apparent' livability; in other words, how healthy and happy people are in a country.

\section{Research Questions}

The empirical question is then whether inhabitants of welfare-states tend to be healthier and happier than inhabitants of otherwise comparable countries that provide less state-welfare.

To answer that question we will first compare across nations that differ in amount of state-welfare effort and inspect whether these nations differ systematically in physical health and subjective enjoyment of life.

As a second step we will compare through time to assess whether health and happiness increased more in the countries where the welfare-state expanded most.

Possible correlations between state-welfare-effort and livability can be spurious. Welfare-states are typically economically developed nations. Economic prosperity could affect livability more than state-welfare as such. Therefore we will try to isolate the effect of state-welfare alone. 


\section{METHOD}

The answering of these questions requires that we have valid indicators of both livability of nations, and state-welfare-effort in these nations. Another requirement is that we have adequate measures for the control variable: economic affluence.

\section{Indicators of Livability}

As noted above, livability of the nation can best be measured by its 'output' in health and happiness of its citizens. A country where people are disease ridden and unhappy is apparently not well livable.

\section{Length-of-life}

The degree to which inhabitants of a country are physically healthy can be measured in different ways: 1) by the incidence of health defects; 2) by health feelings; and 3) by longevity.

Prevalence and seriousness of disease in a country can be assessed by doctors (screening) or by questioning a representative sample (health survey). Symptom scores are typically summed in a health index. There are several problems with this approach. One problem is that the selection of symptoms is rather arbitrary and that it is difficult to assign weights. For example, should colds be included, and how much worse is pneumonia? Another problem is that incidence of disease can be low in a country, because people die young as a result of their first serious illness. That situation is not a hallmark of livability. A more practical problem with this approach is that there are as yet no comparable data on this matter in a sizable number of countries.

Another way is to consider signs of overall health. A subjective approach is to sample how healthy people feel they are. This is mostly done by means of survey questions on 'satisfaction with health'. This method also labors the problem that high survival rates may depress average satisfaction. Moreover, the comparability of satisfactionratings could be reduced by cultural differences in acceptance of health defects. A practical problem is again that data on subjective health are only available for developed nations.

Overall objective health can be measured by life-expectancy in the country; good health tends to manifest in a long life. The link is 
not perfect however; heavy investments in health-care can result in long life in spite of not so good health. As such this indicator may be in the advantage of welfare-states. Data about life-expectancy in nations are of good quality, and available for many nations at different point in time. Though not ideal this is the best indicator of average health we have.

\section{Appreciation-of-life}

The degree to which citizens in a country enjoy life is usually measured by incidence of manifestations of the contrary, such as depression and suicide. A major weakness of this approach is that incidence of extreme dissatisfaction does not bear much information about average satisfaction. Also: dissatisfaction with life does not necessarily lead into depressive disease or suicidal behavior. Further, suicide is likely to be higher in societies that do not taboo self-termination of life, but are for that reason not less livable.

Another approach is asking people how they feel about life. This is common practice in so called 'Quality-of-life surveys'. Two types of questions are being used. Firstly, questions about specific aspects of life, such as perceived adequacy of ones income, fear for crime and thrust in government. Such items typically concern domains of life on which welfare-states are active, such studies being typically instigated by the state. Use of such items would therefore tilt comparison to their favor. As in the case of specific health aspects, there is again the problem of constructing an overall index. Not only is this not well feasible, there are neither sufficient comparable data.

An alternative is questioning about overall appreciation of life$a s-a$-whole. This commonly referred to as 'life-satisfaction' or 'happiness'. There are serious doubts about this approach as well.

Firstly, there is reluctance to believe that simple survey questions about happiness yield meaningful and honest answers. A lot of difficulties have been raised. People would have no opinion, questions would be interpreted quite differently and answers would be biased by social desirability and ego-defense. Elsewhere Veenhoven (1984, chapter 3) has checked these objections empirically, but found little or no support. Though not very precise, answers seem reasonably valid. Lack of precision at the individual level is no problem for comparison at the nation level; measuring faults cancel out in the country-average. 
Secondly, there are objections against the comparison of satisfaction reports across nations. Claims have been made that responses are differently biased in distinct nations, due to cultural variation in language, response tendencies, moral appreciation of happiness and familiarity with the concept. These possible distortions have been checked empirically as well (Ouweneel and Veenhoven, 1990; Veenhoven 1986, 1993). Again no evidence for any serious bias was found. On the other hand validity tests were positive. A test for congruent validity showed sizable correlations with other indicators of apparent livability; with incidence of mental distress as well as life-expectancy. A test for concurrent validity showed that average life-satisfaction tends to be highest in nations that are economically most affluent, politically most democratic, socially most equal and that provide best access to knowledge. Together these nation characteristics explain $77 \%$ of the differences in happiness (Veenhoven, 1993: 50)!

Thirdly, it is claimed that life-satisfaction depends on social comparison within nations, and can therefore not be used for estimating variation in livability across nations. This relativist claim does not stand empirical tests either (Veenhoven 1991, 1995).

Comparable data on average appreciation-of-life around 1980 are now avaiable for 28 nations. There are data about responses to questions about 'happiness' as well as data on responses to equivalent items on 'life-satisfaction'. For several nations time-series are available, covering one to four decades (Veenhoven 1993: tables 1.1.1 and 1.2.1).

\section{Congruent validity}

These indicators of livability seem to reflect a similar phenomenon indeed. Average appreciation-of-life and length-of-life go together; inter-correlations in our 28 nations data-set are: +0.47 (happiness by life-expectancy) and +0.69 (life-satisfaction by life-expectancy). Both indicators of livability are also correlated with a third one: prevalence of mental distress $(r=-0.76$, respectively -0.60$)$.

\section{Indicators of State-Welfare-Effort}

The degree to which nations are welfare-states can be measured in two ways: 1) by the rights for welfare services guaranteed in laws; 
and 2) by the amount of money actually spend on welfare. These indices are referred to as 'legal' and 'financial' indicators.

\section{Legal indicators}

As states operate mostly on the basis of laws, taking stock of welfare legislation allows an estimation of welfare-effort. Two methods have been used.

Estes (1984) measured state-welfare-effort by the senionity of the welfare system, as measured by the year of adoption of its first laws. Laws on five welfare services are considered: pensions, sickness, health care, unemployment and family allowances. It is assumed that welfare services tend to expand over time. Early beginners would therefore tend to provide most rights nowadays. Though there is some truth in that, there are also examples of the contrary. For instance, Sweden was a laggard in welfare-state development, but is now the world's most benevolent welfare-state. On the other hand Britain was a pioneer in state-welfare, but is now in the middle. Data on system seniority are available for a sizable number of nations; rich nations as well as poor nations.

The other way is to sum welfare entitlements, by making an inventory of current welfare-rights in nations and consider their scope. An example of this approach is Esping-Andersen's (1990) 'Decommodification score'. This indicator reflects a) the range of legal entitlements; b) the level of income replacements involved; and c) access to benefits. Four welfare services are considered: old age pensions, insurance for sickness, permanent disability and unemployment. A problem with this approach is that the package of welfare services is not identical in all welfare states. So this indicator compares only to what extend welfare states provide more or less of the same, but does not grasp unique services and package composition. Comparable data on state-welfare entitlement are currently available for rich nations only.

\section{Financial indicators}

Another possibility is to compare the amount of money states spend on welfare. Expenditures can be estimated in two ways; either by adding the costs of all separate welfare-services, or by departing from global government expenditures and subtracting non-welfare entries. 
Indicators of the former kind commonly cover major welfarecategories, such as 'health-care', 'housing' and 'social security'. One problem with this method is that these categories are not identically defined in national accounts. Another problem is distinguishing between public and private welfare services. International agencies have tried to homogenize the data on social-security expenditures. OECD, ILO and IMF provide estimates based on slightly different sources and definitions. All three these indicators will be used here.

A common drawback of these indicators is that welfare expenditures depend not only on generosity of the welfare system, but also on external conditions. For instance, unemployment benefits may be meager in a country, but the total expenditures are nevertheless high because of mass unemployment. Likewise, expenditures for old age pensions depend heavily on the age composition of the population. Data on welfare expenditures are available for a lot of nations. The ILO estimates cover most countries and allow comparison trough time for a considerable number of nations.

There are several ways to estimate state-welfare-effort by means of total government expenditures. The first and most global one is to add all expenditures, assuming that the biggest spenders tend to be the most beneficial welfare providers. A variant of that approach is to consider only expenditures for government services and salaries, called 'government final consumption'. High expenditure on that matter is indicative for an active state that is likely to be much involved in welfare provision. Other estimates of this kind try to eliminate entries that do not concern welfare. One can leave out capital expenditures and focus on 'disbursements'. A major problem with this approach is that government expenditures involve more than welfare expenditures. In fact it measures global state-activity rather than specific welfare-state-activity. For the sake of completeness we will nevertheless consider these indicators as well. As none of them stands out as the best, all will be used in the analysis.

\section{Congruent validity}

To assess whether all these indicators measure the same thing, intercorrelations were computed. This was done separately for rich and poor nations. Only for the rich nations do we have complete data. See Table I. 
The correlation between the two legal indicators ( $\mathrm{nr} 1$ and 2 ) is modest: $r=+0.46$. Both correlate better with the financial indicators than with each other.

Intercorrelations among the financial indicators are consistently sizeable, with the exception of government consumption (nr 9). The highest correlations are produced by the ILO-index of social security expenditures ( $\mathrm{nr}$ 5). Fortunately that indicator is also available for most poor countries.

\section{Analysis}

We will first compare across nations to assess whether nations that provide most state-welfare tend to be the most livable ones. For that purpose we will first compute zero-order correlations between the various indicators of state-welfare effort and our indicators of livability. If positive correlations emerge, we will inspect to what extend these can be attributed to parallel differences in economic affluence. Three methods are used to that end: separate analyses among rich and poor nations, computing partial correlations and analysis of residuals.

Next we compare through time to assess whether livability increased more in the nations where state-welfare expanded most. Again the possible effects of parallel changes in economic development are controlled.

\section{RESULTS}

Below we will first consider the effect of state-welfare on average appreciation-of-life; first by comparing across nations and next by comparing through time. This analysis limits to 27 nations, of which 19 rich ones. Data on average life-satisfaction in nations are limited as yet.

Subsequently, we will consider the effect of state-welfare on length-of-life; again first cross nationally and next cross temporally. For this purpose we have data on 97 nations. 


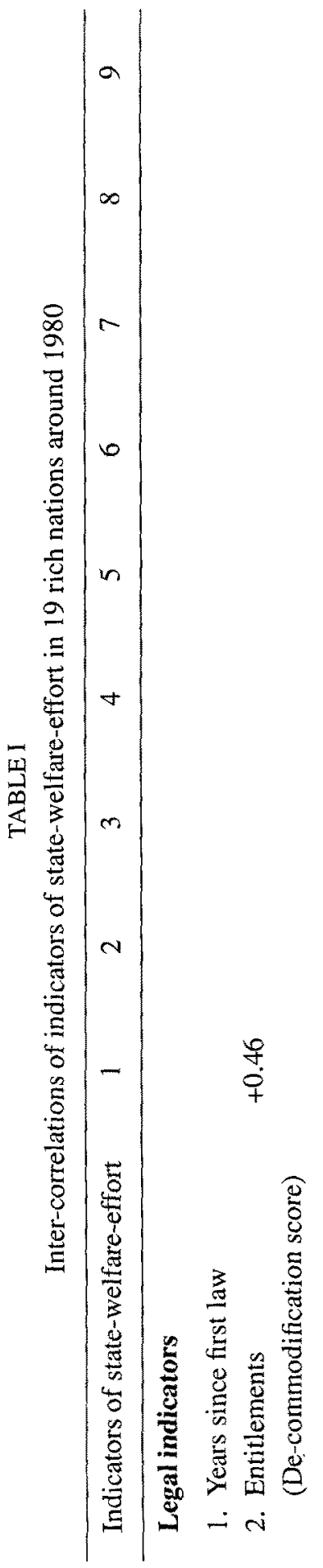

$$
\begin{aligned}
& \text { iे } \\
& \stackrel{2}{\stackrel{n}{7}} \\
& \text { के }
\end{aligned}
$$

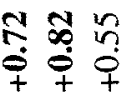

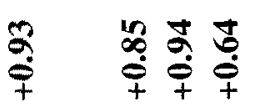

$$
\begin{aligned}
& \text { ई尺 }
\end{aligned}
$$

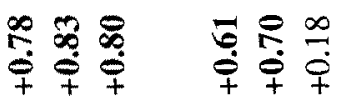

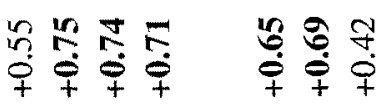

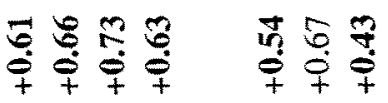

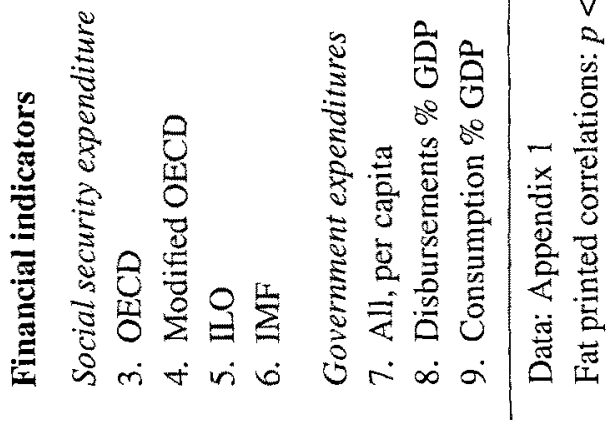




\section{State-Welfare and Appreciation-of-Life}

\section{Comparison across nations}

Table II presents the correlations between state-welfare-effort and subjective satisfaction with life. The correlations are based on somewhat different nation sets.

When all nations are considered together, a positive zero-order relationship appears. See Table II left column. The average correlation is about +0.35 . Three correlations reach the level of statistical significance. The pattern is similar across indicators of state-welfareeffort; legal indicators correlate equally well as financial indicators. The two cases where no correlation appears (welfare indicator 2 and 3) are based on small samples of largely rich nations.

Correlations tell only half the story. Analysis of the scattergrams reveals a non-linear relationship. See Figure 1. The correlation is caused by the difference in happiness between countries that provide no or little state-welfare. There is no difference in average happiness between the nations that provide little or much state-welfare. The cases in the slanting part of the curve are all poor nations; the cases in the horizontal part are the rich nations.

The convex pattern may mean two things. It may mean that state welfare is subject to the law of diminishing utility. In other words: that a minimum of state-welfare is required to create a livable society, but that extra state-welfare above that level does not yield greater livability. The turning point is then at about $10 \%$ of the national income spend for state-welfare. The other possibility is that the relationship is spurious, and in fact reflects parallel differences in economic development. The same convex pattern emerges if we cross life-satisfaction with economic prosperity of the country. Average life-satisfaction is even more closely related to income per head $(r=+0.70)$ than to state-welfare-effort.

To check this latter possibility we first considered rich and poor nations separately (income per capita $>\$ 4500$ or $\leq$ ). This changed the picture drastically. In the set of 20 rich nations, no relationship remains. Among the 8 poor countries little relationship is left either (data not shown). We next computed partial correlations. See Table II, second column. None of these partial correlations differs significantly from zero. 


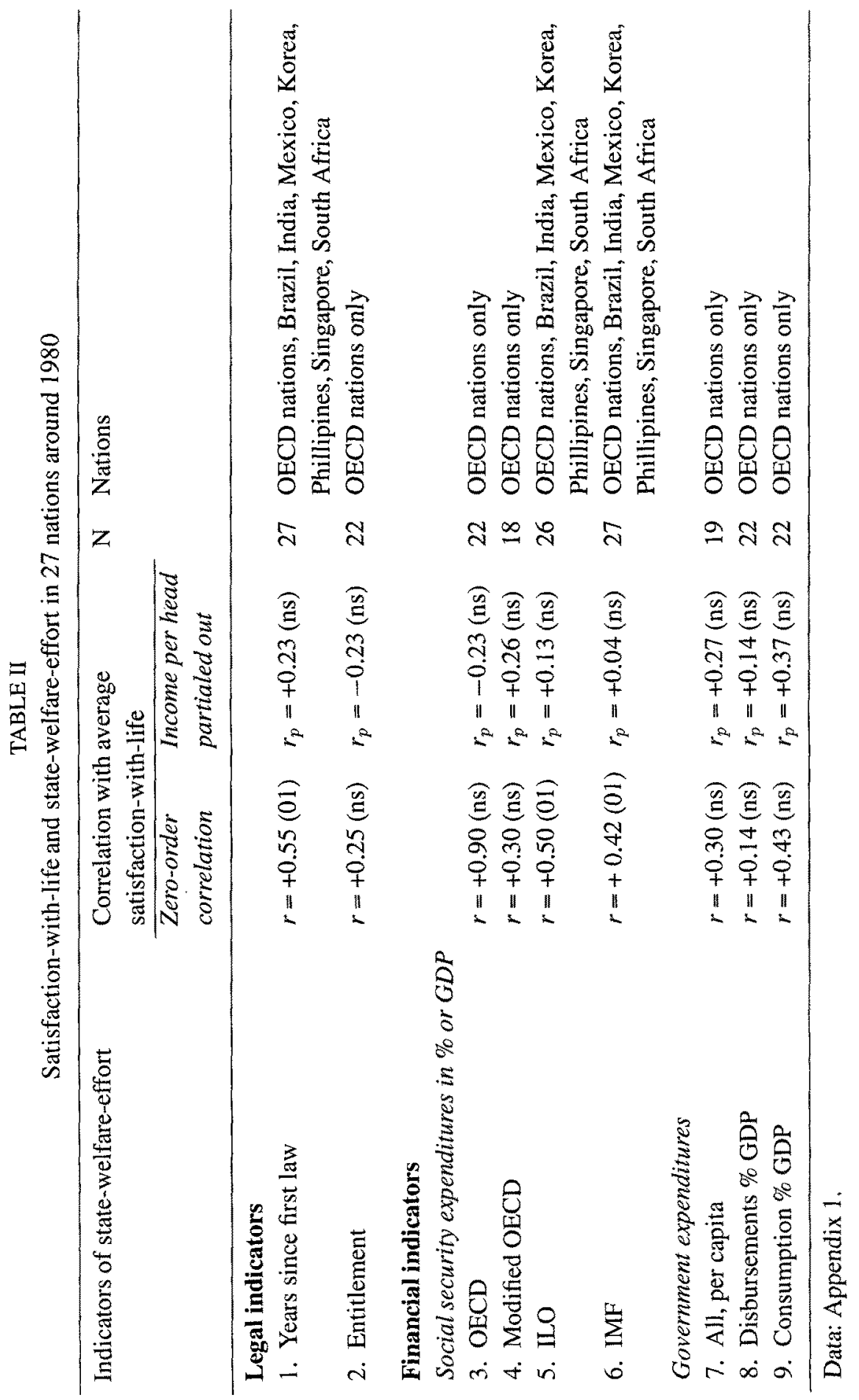


appreciation-of-life

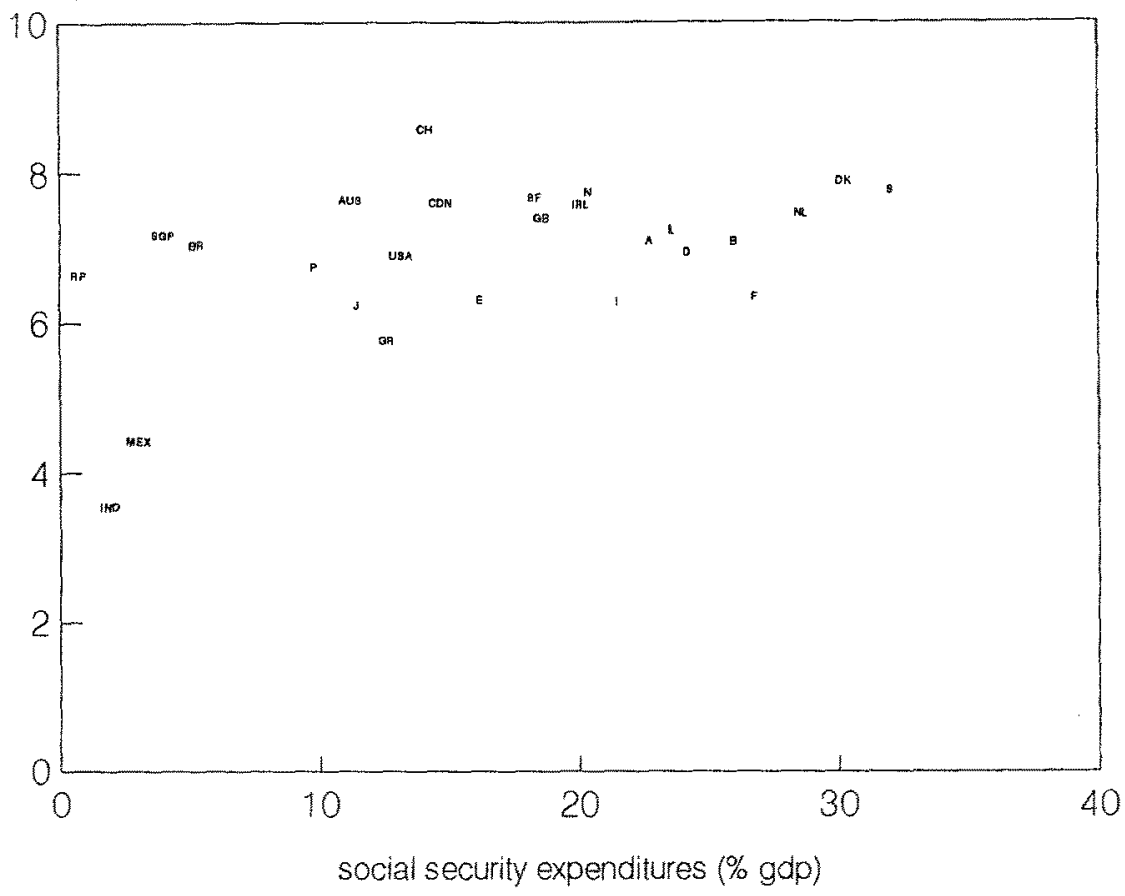

Fig. 1. Welfare-expenditures and appreciation-of-life in 26 nations 1980: Scattergram. $r=+0.50 p<0.01$. Nation codes: Appendix 2 .

This analysis is visualized in the plot of residuals in figure 2 . In that scattergram the quarter left-under depicts the nations where the state provides less welfare than usual at their level of economic prosperity, and where citizens are also less happy than predicted on the basis of economic prosperity. The USA is the most prominent case in this quarter. In the quarter right-above are the countries where the state provides more welfare than usual at that level of economic prosperity, and where citizens are disproportionally happy. Prominent cases in this quarter are Ireland (IRL) and Sweden (S). So far the observations are in line with the theory that an active welfare-state creates a more livable society. However, this is not the general pattern. There is no concentration in the quarter left-under and right above. We see also countries in the quarter left above, that combine relatively low state-welfare with relatively high happiness. Singapore (SGP) and Switzerland $(\mathrm{CH})$ are the most clear cases here. Likewise, we also find countries in the quarter right under; 


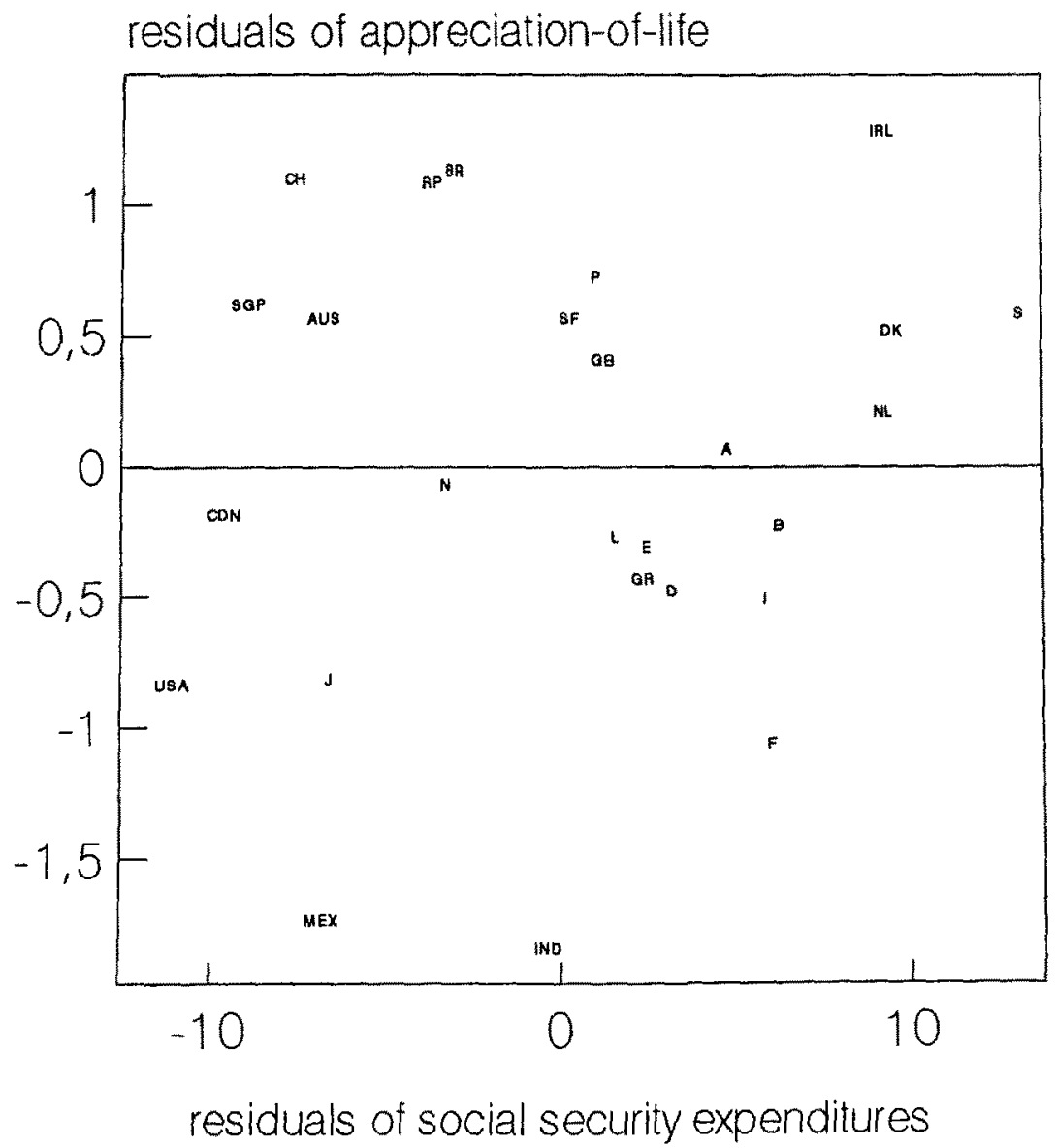

Fig. 2. Welfare-expenditures and life-satisfaction in 27 nations 1980: Effects of income per head on both variables removed (plot of residuals). $r=+0.13 \mathrm{~ns}$. Nation codes: Appendix 2.

the combination of relatively much state-welfare with relatively low happiness. France $(F)$ is the typical case here. Together these 28 cases do not reveal any dominant pattern. The correlation of residuals is hence low, and not significantly different from zero $(r=+0.13 \mathrm{~ns})$.

Next to this pattern of correlation with 'life-satisfaction' we also considered correlations with average report of 'happiness' in nations. The results are almost identical. (Tables not shown.)

Comparison through time

This non-difference does not prove that state-welfare does not make happier. It is possible that Father State was more welcome in the 
initially most unhappy countries, and that differences in happiness would have been greater without. In order to grasp causality we must also consider change through time. Therefore we inspected whether countries in which state-welfare expanded most show a relative increase in life-satisfaction.

During the last decades state-welfare expanded in all rich nations. Of only a few of these do we have data on the development of life-satisfaction. See Table III. The data show little advance in lifesatisfaction at all, nor systematic difference between slow and fast welfare-expanders. There is a tendency to lagging of life-satisfaction in the nations where state-welfare expanded most. However, the number of nations is too small to allow definite conclusions.

\section{State-Welfare and Length-of-Life}

Data are more abundant in this case. Of 97 countries we know both the degree of state-welfare around 1980 and life-expentancy at that time. Of 37 nations we also have data on changes in both variables over the last decades.

\section{Comparison across nations}

Zero-order correlations between indicators of state-welfare and life-expectancy differ markedly. See Table IV, left column. Three correlations are positive, of which two significant, the other six correlations are negative, all insignificant. The differences are probably due to variation in nation-sets. The significantly positive correlations appear in the most sizable nation-sets, in which a large number of poor nations are involved. See respectively row 1 and row 5 in Table IV.

For three indicators $(2,3$, and 4$)$ the nationset is the same as in the analysis of satisfaction-with-life (Table II). The correlations are highly similar in these cases.

Again the scattergrams show a convex pattern; among the poor nations at the left of the figure a steeply ascending slope, and the rich nations at the right on an almost horizontal line. Figure 3 presents the plot of indicator 5 (welfare expenditures ILO) against life-expectancy.

Once again, we considered whether the relationship is the spurious effect of parallel differences in economic development of these 


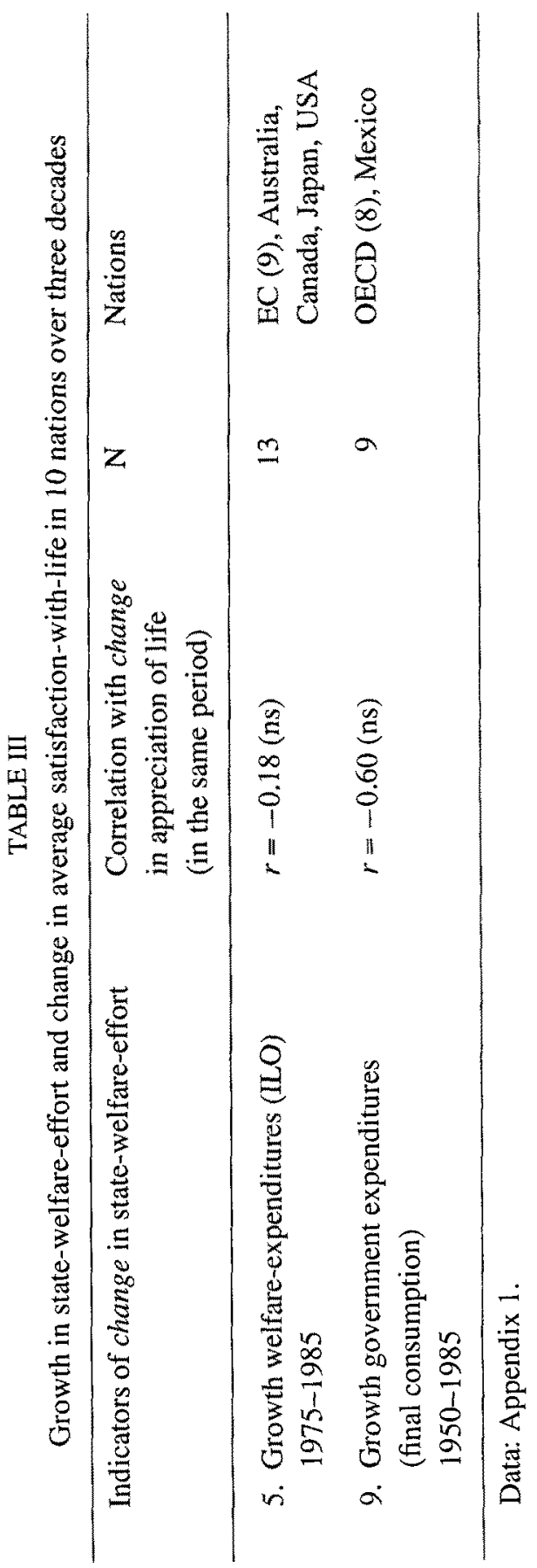




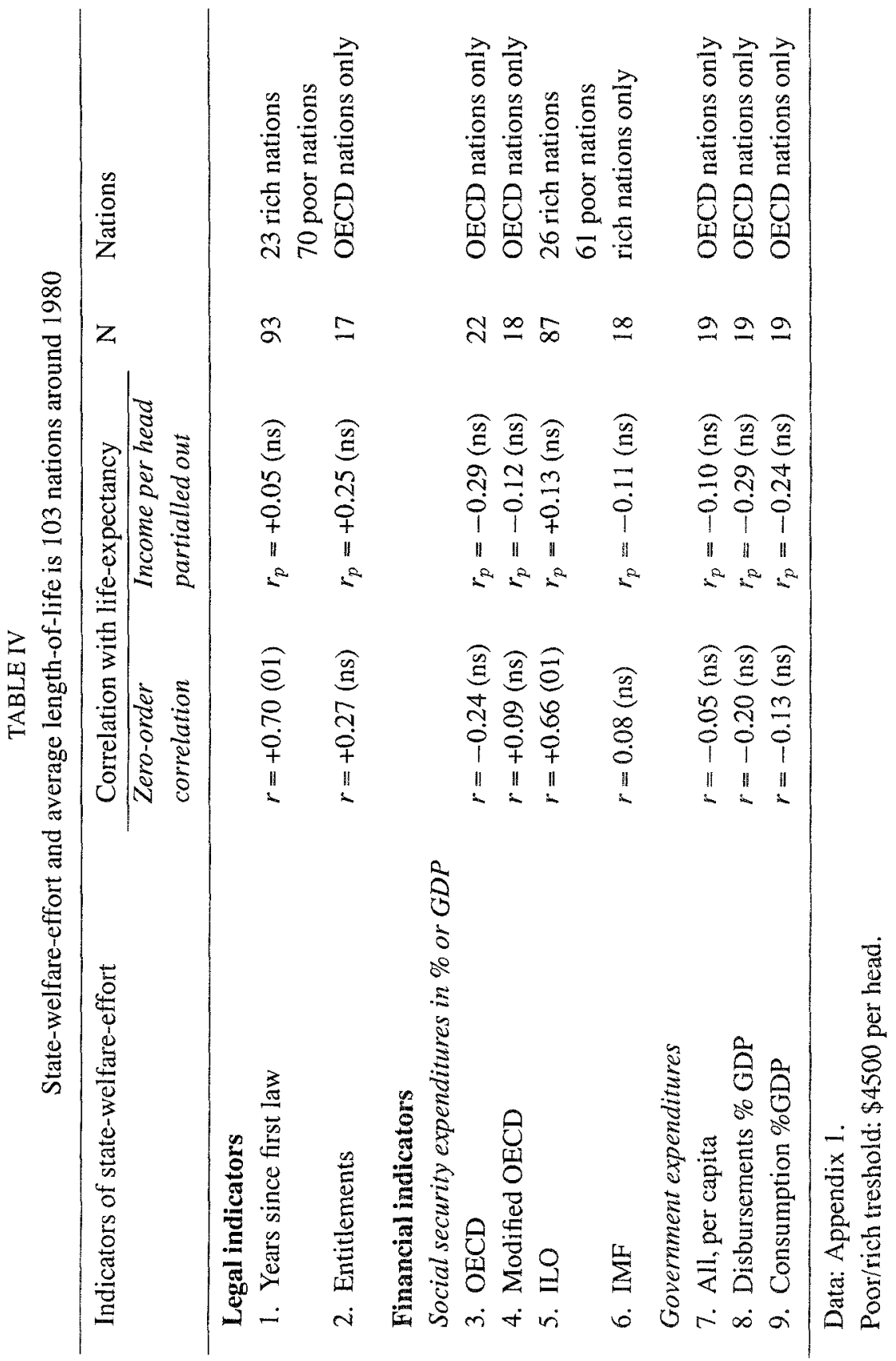


life-expectancy (years)

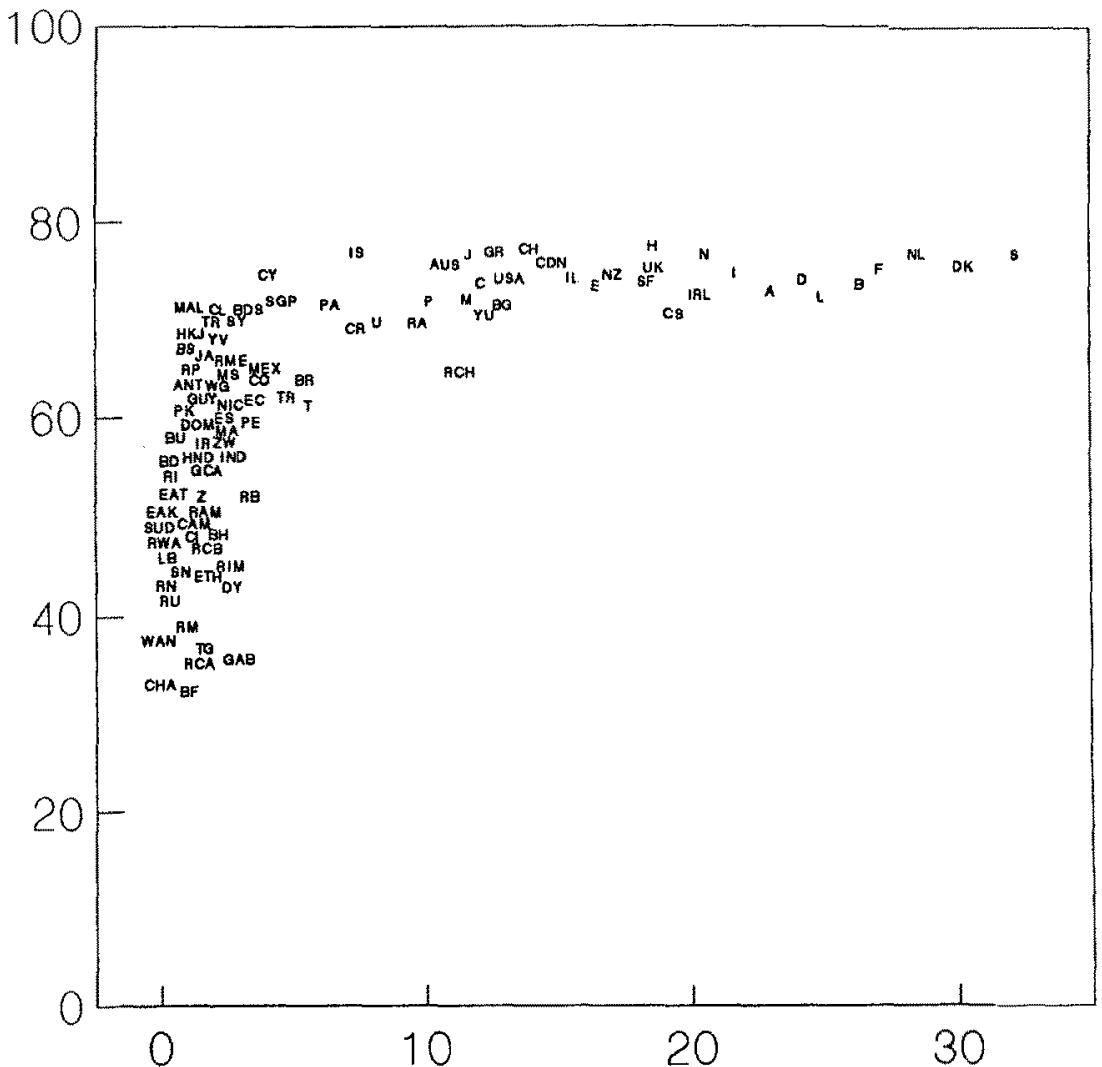

social security expenditures (\% gdp)

Fig. 3. Welfare expenditures and length-of-life in 97 nations 1980: Scattergram $r=+0.67 p<0.01$. Nation codes: Appendix 2 .

countries. To that end we first computed correlations for poor and rich nations separately. This time, the pattern is different among rich and poor nations. Among rich nations there is again no correlation between state-welfare and life-expectancy. However, among the poor nations significant positive correlations emerge (data not shown).

Among the poor nations considered here, there are still sizable difference in economic development. The correlations can therefore still be artefactual. Therefore we also computed partial correlations. See Table IV right column. Now all correlations are reduced to 
insignificance. Separate partial analysis of the poor nations yields the same results (data not shown). Even among the poor nations there is no independent relationship between state-welfare-effort and life-expectancy.

This pattern is visualized in the plot of residuals on Figure 4. If there had been an independent effect of state-welfare on lifeexpectancy, this would have manifested in concentrations in the quarters left-under the right above. Life-expectancy would have been lower than usual at their level of economic prosperity in the nations that provide less state-welfare than usual at that level (left under), and higher than predicted by economic prosperity in the nations that provide more state-welfare than usual at that level of living (right above). However, no such pattern appears. In fact there is in the quarter left under only one clear case. This is Kuwait, which is in fact positioned outside the range shown here. The welfare score of that country is dubious however. ${ }^{2}$ The USA is also in the quarter left below, but pretty close to the middle of the entire pattern. There are more cases in the quarter right above. For example in Ireland (IRL) both state-welfare and life-expectancy are greater than usual at that level of economic prosperity. However, there are also combinations of relatively low state-welfare and high livability. See for instance Malaysia (MAL) and Venezuela (YV) in the quarter left above.

Figure 4a presents the poor nations separately. A vertical oval pattern emerges. The dispersion on the vertical axis indicates great differences in life-expectancy among these countries, irrespective of economic development. The concentration at the horizontal axis means that there is little independent variation in state-welfare-effort among the poor countries. ${ }^{3}$ The direction of the midline through the oval (vertically top-down rather than sloping from left under to right above) indicates that the large differences in life-expectancy have little relationship with the small differences in state-welfare-effort. Apparently, affluence-independent-differences in life-expectancy depend on other things than state-welfare-effort. Possibly the differences in life-expectancy are due to cultural variation in health behavior or racial variation in wiriness.

Figure $4 \mathrm{~b}$ presents the rich nations separately. Now a horizontal oval appears, indicating small economy-independent differences in life-expectancy, but sizable independent differences in state-welfare- 
residuals of life-expectancy

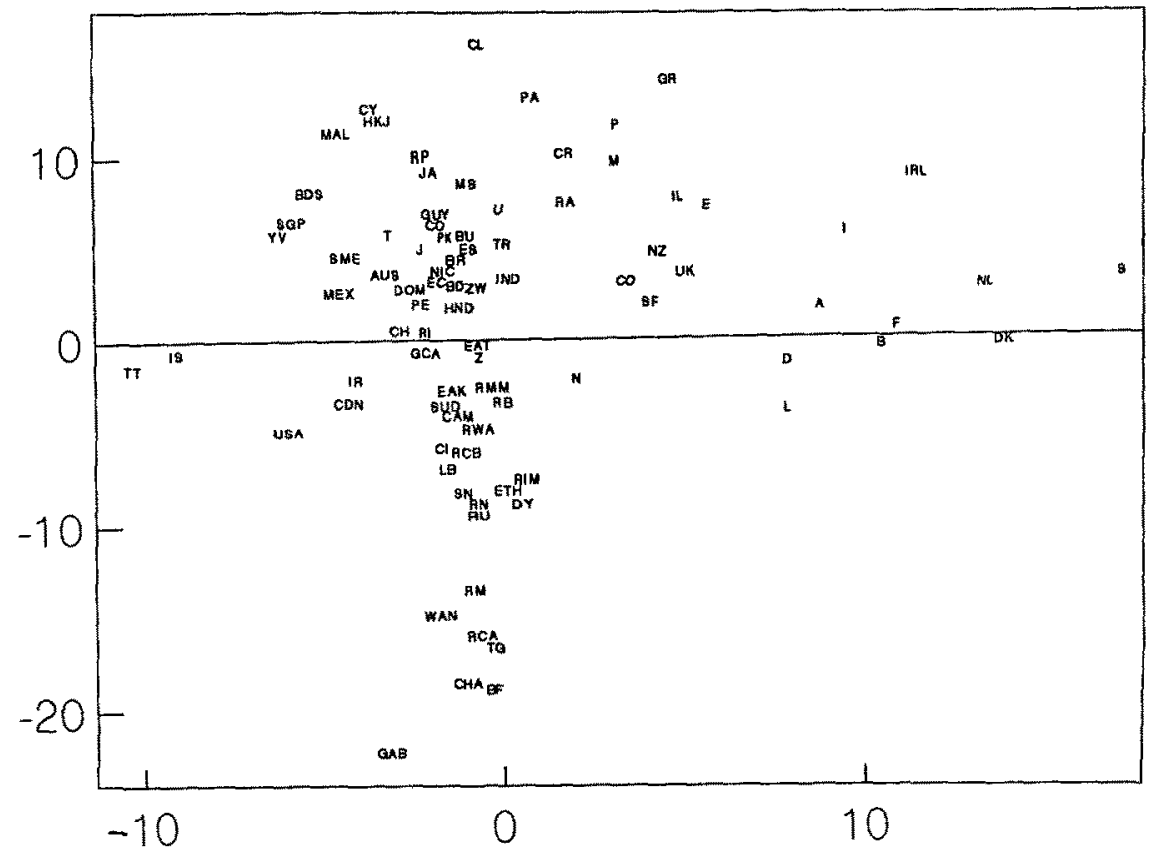

residuals of social security expenditures

Fig. 4. Welfare-expenditures and length-of-life in 88 nations 1980: Effects of income per head on both variables removed (plot of residuals). $r=+0.13$ ns. Nation codes: Appendix 2.

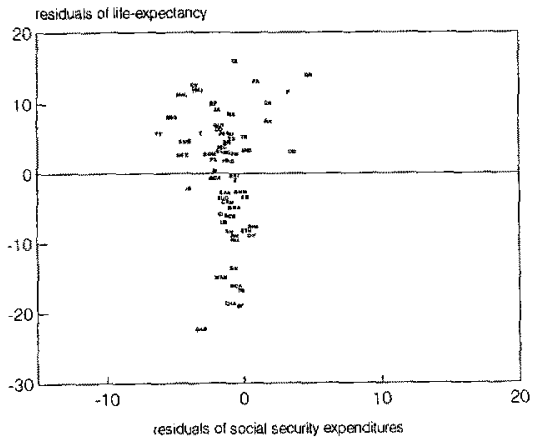

Fig. 4a. 69 poor nations separately.

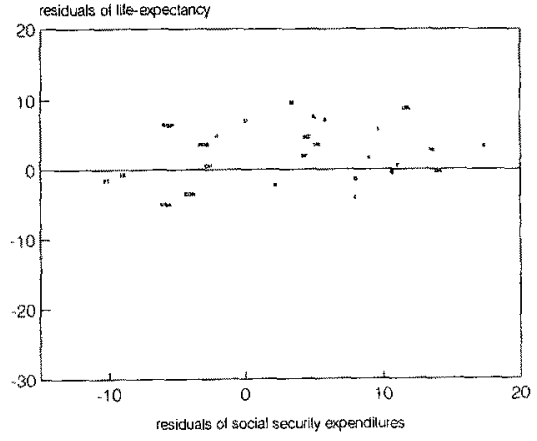

Fig. 4 b. 28 rich nations separately.

effort. In the left of that oval are Australia (AUS), Canada (CND) and the USA. In the right of the oval are the nations of North-West Europe. This time, the small differences in life-expectancy bear no 
relationship to the big differences in state-welfare. In this figure we see the two contrasting cases that are often mentioned by advocates of the welfare state: the USA that would provide relatively low state-welfare and pay the price of lagging life-expectancy, while in Sweden (S) the extended welfare state would prove it effectiveness by a disproportionally higher life-expectancy. As we can see, there is indeed a difference of that kind. However, these cases are again not representative of the general pattern.

\section{Comparison through time}

During the last decades, state-welfare effort has expanded in most of the nations considered here. In the same period average lifeexpectancy has increased considerably as well. The question is now whether the gain in years was greater in the countries where statewelfare expanded most, and whether this effect is independent of variation in economic growth.

Table $\mathrm{V}$ presents correlations. All the zero-order correlations are negative, which means that life-expectancy increased most in the nations where state-welfare expanded least. This pattern is reproduced when rich and poor nations are considered separately (data not shown). The partial correlations are also negative. See again Table V.

Does this mean that expansion of state-welfare tends to reduce life-expectancy rather than improve it? Not necessarily. This result can be artefactual. In the nations considered here, life-expectancy was not the same initially. These differences matter; the higher average life-expectancy is at start, the more difficult it is to gain extra years. Therefore, the data are now presented by degree of lifeexpectancy before expansion of state-welfare. See Tables VIa and VIb.

Table VIa presents data on 36 nations over a 20 year period. This nation set contains poor nations as well as rich nations. In three of these nations state-welfare-effort decreased more than $2 \%$ in this period (Italy, Guyana and Venezuela). In nine cases state-welfareeffort remained at about the same level (e.g. Bolivia and Australia). In most of the countries considered here state-welfare-effort increased (most rich nations, Costa Rica, Panama and Turkey). We can now inspect whether less years of life were won in countries where state- 


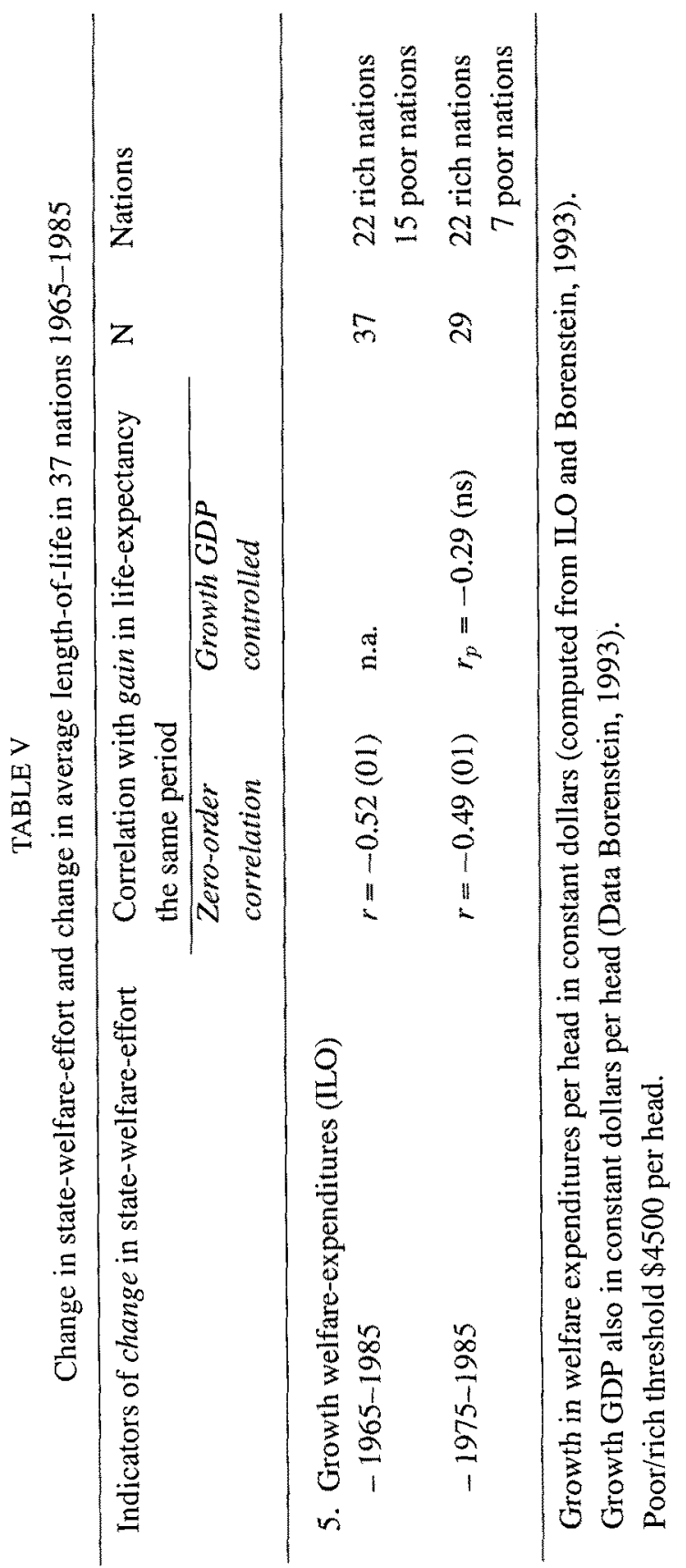




\section{TABLE VIa}

Change in state-welfare expenditures and gains in life-expectancy by lifeexpectancy at start in 36 nations (rich and poor) 1965-1985

\begin{tabular}{|c|c|c|c|}
\hline \multirow{3}{*}{$\begin{array}{l}\text { Life-expectancy } \\
\text { in years } 1965\end{array}$} & \multirow{2}{*}{\multicolumn{3}{|c|}{$\begin{array}{c}\text { Gains in life-expectancy in years } 1965-1985 \\
\text { Change social security expenditures 1965-1985 } \\
\text { as a \% of GDP (ILO) }\end{array}$}} \\
\hline & & & \\
\hline & $\begin{array}{l}\text { Less expenditures } \\
(\leq-2 \%)\end{array}$ & $\begin{array}{l}\text { Stable expenditures } \\
(-2 \text { to }+2 \%)\end{array}$ & $\begin{array}{l}\text { More expenditures } \\
(+>2 \%)\end{array}$ \\
\hline Low: less than & & 9.0 Bolivia & 12.8 Panama \\
\hline 60 years & & $\begin{array}{l}\text { 13.9 Chili } \\
\text { 12.3 Colombia } \\
-1.2 \text { El Salvador } \\
\text { 8.3 Guatemala } \\
\text { 17.9 Togo }\end{array}$ & 12.3 Turkey \\
\hline Middle: 61 to & 8.8 Guyana & 9.4 Jamaica & 7.3 Austria \\
\hline 70 years & 6.6 Venezuela & 5.1 Trinidad & $\begin{array}{l}\text { 11.3 Costa Rica } \\
\text { 6.6 Cyprus } \\
\text { 5.6 Finland } \\
\text { 5.2 Greece } \\
\text { 5.2 Luxembourg } \\
\text { 8.3 Portugal }\end{array}$ \\
\hline $\begin{array}{l}\text { High: } 70 \text { years } \\
\text { or more }\end{array}$ & 4.7 Italy & 4.8 Australia & $\begin{array}{l}\text { 2.8 Belgium } \\
\text { 4.4 Canada } \\
\text { 2.2 Denmark } \\
\text { 4.6 France } \\
\text { 4.6 Germany } \\
\text { 2.2 Ireland } \\
\text { 3.0 Israel } \\
\text { 8.1 Japan } \\
\text { 2.8 Netherlands } \\
\text { 3.0 New Zealand } \\
\text { 2.2 Norway } \\
\text { 3.5 Sweden } \\
\text { 5.2 Switzerland } \\
\text { 3.4 UK } \\
\text { 4.5 USA }\end{array}$ \\
\hline
\end{tabular}

Data: Appendix 1. 
TABLE VIb

Growth in state-welfare-expenditures and gains in life-expectancy by lifeexpectancy at start in 19 rich nations $1950-1980$

\begin{tabular}{|c|c|c|c|}
\hline \multirow{3}{*}{$\begin{array}{l}\text { Life-expectancy } \\
\text { in years } 1950\end{array}$} & \multirow{2}{*}{\multicolumn{3}{|c|}{$\begin{array}{c}\text { Gains in life-expectancy in years 1960-1980 } \\
\text { Growth social security expenditures } \\
1950-1980 \text { in \% of GDP (ILO) }\end{array}$}} \\
\hline & & & \\
\hline & $\begin{array}{l}\text { Low increase: } \\
<+5 \%\end{array}$ & $\begin{array}{l}\text { Middle increase: } \\
5 \text { to } 10 \%\end{array}$ & $\begin{array}{l}\text { High increase: } \\
>+10 \%\end{array}$ \\
\hline Low: $69-70$ years & 11.6 Japan & $\begin{array}{l}\text { 5.1 Austria } \\
\text { 7.5 Finland } \\
\text { 5.7 Germany (W) } \\
\text { 7.1 Italy } \\
\text { 5.8 USA }\end{array}$ & $\begin{array}{l}4.8 \text { Belgium } \\
4.2 \text { Ireland }\end{array}$ \\
\hline Middle: 71 years & $\begin{array}{l}\text { 5.9 Austria } \\
\text { 6.1 Canada } \\
\text { 3.5 New Zealand }\end{array}$ & 4.8 Britain & 5.8 France \\
\hline High: $72-74$ years & 5.1 Greece & & $\begin{array}{l}\text { 2.9 Denmark } \\
\text { 3.4 Netherlands } \\
\text { 3.6 Norway } \\
\text { 4.1 Sweden }\end{array}$ \\
\hline
\end{tabular}

Data: Appendix 1.

welfare diminished than in the countries where it increased. This appears not to be the case.

Of the eight countries that had a low life-expectancy at start (top row in Table VIa), six maintained the same level of statewelfare during this period (middle cell), while in two countries state-welfare expenditures increased (Panama and Turkey). The gain in life-expectancy in the latter two countries is impressive (12 years). However, the gain in life-expectancy is even higher in some of the countries where state-welfare did not increased (Chili and Togo).

Of the eleven countries that had a medium level of life-expectancy at start, the gains in life-expectancy are considerable as well. See the middle row in Table VIa. Now there are also two cases where state-welfare-expenditures decreased (Guyana and Venezuela). The average gain in life-expectancy in these two nations ( 7,7 years) is not below the average gain in the two countries where welfare-expen- 
ditures remained at the same level $(7,8$ years), or the average gain in the seven countries where state-welfare-expenditures increased $(7,1$ years). Though the highest gain is achieved in one of the countries where state-welfare increased (Costa Rica, 11,3 years), cases of low gain figure in this category as well (Greece and Luxembourg, both 5,2 years).

Of the 17 nations that had a high life-expectancy at start (bottom row in Table VIa), only one reduced state-welfare in this period (Italy) and only one maintained the same level (Australia). The gains in life-expectancy in these countries (4,7 respectively 4,8 years) do not stay behind the gains in all other countries, where state-welfare increased. The average gain in these latter countries is 3,1 years.

In Table VIa most of the rich countries are lumped together in the cell right under. The Table does not show the considerable difference in growth of welfare-expenditures among these countries. Therefore the rich countries are also presented separately in Table VIb. Table $\mathrm{VIb}$ not only specifies growth in state-welfare, but it also considers gains in life-expectancy on a finer scale. The data concern a longer period; now 30 years. ${ }^{4}$

These data do not show greater gains in life-expectancy in countries where state-welfare expanded most either. In fact, there is rather a tendency to the contrary. Among the rich countries that started at the lowest life-expectancy, the one that raised welfare expenditures least realized the greatest gain in life-expectancy (Japan), whereas the gain was lowest in the two countries that expanded welfare most (Belgium, Ireland). Likewise, among the nations that started at the medium level, the modest expanders won most years (Australia, Canada). At the highest level the same pattern appears: more years won in the case where state-welfare increased least (Greece). In fact only a few cases fit the prediction of greater gains by the greatest expanders: at the medium level respectively New Zealand, Britain and France.

As a final check we computed the partial correlation between growth of welfare-expenditures and increase in life-expectancy, controlling for life-expectancy at start; $r_{p}=-0.08(\mathrm{~ns})$. 


\section{DISCUSSION}

The results are summarized in the exhibit below. Clearly, there is no relationship between the amount of state-welfare in the country and its apparent livability. There is not even evidence that a minimum level of state-welfare is required. The findings are disturbing for both parties in the discussion. Though welfare-states do not show superior livability, they do not perform worse either.

Summary of results

\begin{tabular}{|c|c|c|}
\hline \multirow[t]{2}{*}{ Indicators of livability of nations } & \multicolumn{2}{|c|}{ Relationship with state-welfare-effort } \\
\hline & $\begin{array}{l}\text { Greater in nations } \\
\text { where state provides } \\
\text { most welfare? }\end{array}$ & $\begin{array}{l}\text { More increased in the } \\
\text { nations where state- } \\
\text { welfare expanded most? }\end{array}$ \\
\hline Average satisfaction-with-life & NO & NO \\
\hline Average length-of-life & NO & NO \\
\hline
\end{tabular}

Disappointment in the results usually makes validity doubts more pressing. Therefore we will first consider the possibility that the observations are not adequate. Next we will explore some possible substantive explanations. In connection some policy implication will be mentioned. We will close with the enumeration of some themes for further research.

\section{Validity of the Results}

\section{Validity of indicators}

One reason to doubt the results could be that the measures may be inadequate. There can be problems in the indicators of state-welfareeffort as well as the two measures of livability.

Indicators of state-welfare effort. Each for themselves these indicators have their limitations; remember page 8-11 and the discussion on their applicability to the newly rich Gulf-states (note 2). Still, the inter-correlations of these indicators showed high congruent validity (Table I). Also, the correlations with indicators of livability are highly similar. Remember the Tables II and IV. ${ }^{5}$ There is thus little reason to expect that other indicators of state-welfare will produce different results. 
Indicators of Livability. There is little reason to doubt the data on life-expectancy; vital statistics may be inaccurate in some countries, but systematic distortion is unlikely to be involved. There is more doubt about the quality of our data on life-satisfaction. These survey data may involve differential sampling error; for instance underrepresentation of the homeless. Cross national comparability may also be hampered by cultural variation in response bias. Elsewhere, these possibilities have been considered in detail. Validity checks showed little distortion in responses to questions about happiness (Veenhoven, 1984, 1993). Moreover, this study showed that 'soft' life-satisfaction relates identically to economic prosperity and state welfare as 'hard' life-expectancy.

\section{Period too short?}

Still one could argue that life-expectancy and life-satisfaction are not appropriate as measures of current livability of nations, because these outcomes could depend very much on past conditions. Lifeexpectancy could depend very much on health-habits of earlier generations and on nutrition in the first years of life. Life-satisfaction in a country could be geared by traditional outlook on life. As a result these indicators would react with considerable delay. This argument presumes that life-expectancy and life-satisfaction are rather fixed and adjust at best very slowly.

This appears not to be to case. Considerable changes have been observed in periods less than a decade with rather evident immediate causes. For instance, life-expectancy gained 11.6 years in Japan between 1950 and 1980, largely as a result of improvements in medical care and standard of living. Likewise, life-satisfaction rose considerably in the post-war decade in the West European nations that had suffered occupation or defeat. Elsewhere, Veenhoven (1994) has shown in more detail that average life-satisfaction is sensitive to current quality-of-life.

Another reason to doubt the findings could be that positive effects of state-welfare show up quickly, but that its negative effects manifest only in the long run. For example, the believed negative effect on work ethics could present not until one or two generations later. This would imply that the non-difference observed now will turn into a negative effect later. 
In this context it is worth remembering that our first indicator of state-welfare effort measures in fact the lifetime of the system. This is Estes' 'Welfare Index', which is based on the year of adoption of first welfare laws. As such it dates back to the beginning of this century. Delayed deterioration should appear in lower livability of the eldest welfare-states. As we have seen this is not the case. The senior welfare states Britain and Germany do not stand out as less livable.

\section{Control for economic prosperity too severe?}

Some zero-order correlations suggest that welfare states are more livable, but after control for economic prosperity of the countries involved, all correlations were reduced to insignificance. Does that mean that the greater livability of the welfare-states is caused by their wealth rather than by their state-care? That inference is correct if expansion state-welfare depends entirely on economic development. It certainly does to a great extend, but does it entirely? There are good reasons to assume that state-welfare not only burdens the economy, but stimulates it in several ways as well: e.g. by its anticyclical effects. ${ }^{6}$ If so, the control for income per head also removed true effects of state-welfare.

We do not know to what extend state-welfare boosts the economy, but suppose we would. Suppose that some $25 \%$ of the shared variance of economic prosperity and state-welfare is due to effects of the latter on the former. Would that change the picture? Not where the rich nations are concerned. Among these, there is no significant zeroorder correlation between state-welfare-effort and livability, and neither a correlation with economic wealth. So control for economic prosperity could not change that picture. However, among the poor nations all these variables are sizably correlated. In this case, the control for prosperity can have obscured an effect of state-welfare. If so, state-welfare would add somewhat to livability in poor nations, but not in rich ones.

\section{Substantial Explanations}

Suppose that there is really no difference in livability between nations that provide much or little state-welfare. That phenomenon can then be explained in two ways. One explanation could be that we can live well without welfare. The other explanation is that we need welfare, 
but not necessarily state-welfare, because other welfare suppliers perform equally well.

\section{Need for welfare}

What we call 'welfare' is largely income supplementation in cases of illness, disability and old age. Welfare-systems are mutual arrangements for income transfer from the lucky to the unlucky, that guarantee a minimum level of living for everybody. All human societies involve welfare systems, mostly in moral obligations to help relatives. It is rather evident that life-expectancy would be considerably lower if there was no welfare at all. A lot of people would starve. That prospect would result in lower satisfaction-with-life as well. So, the observed non-difference cannot mean that welfare does not matter to livability at all.

Though no society is livable without any welfare, societies that provide most welfare are not necessarily the most livable. Like most services, welfare is probably subject to the law of diminishing returns. Seen in this light the observed non-difference can mean that most present day societies provide the required minimum.

Welfare provision above the minimum may also surpass a maximum and then reduce livability; for instance when care becomes smothering and the price soars. If so, we should see a negative trend among the most developed welfare states. There are indeed indications of that kind, in the negative correlations in Table III and V. On the other hand cross-sections show no negative pattern among rich nations. See Table II and IV. For the time being, there is no convincing evidence of welfare surfeit.

\section{Welfare providers}

We have considered state-welfare-effort in nations; not total welfareeffort. In all nations non-state corporations provide welfare-services as well: commercial insurance companies, firms who pay part of the wages in social security entitlement, charity organizations and families. In the rich countries these non-state services typically supplement a minimum guaranteed by the state. In most poor nations the family is the main provider.

In this light, the observed non-difference could mean that the state is no better welfare provider than non-state institutions. In other words, that non-state welfare tends to be 'functionally equivalent'. 
No doubt, all systems of welfare provision have specific advantages and disadvantages, but apparently the balance tends to be about the same.

If so, that does not mean that state-welfare has never been superior or will never be. The comparative effectiveness of welfare supply systems is likely to be contingent on welfare services concerned and on the socio-political conditions in which these are produced. Possibly, state-welfare was superior for the provision for old age care in era of dissolving family ties and unexpected lengthening of life. Also Zapf (1994) is probably right in that individualisation in modern societies renders state-welfare indispensable. In fact, statewelfare exists in all developed societies. Even in the USA social security expenditures take more than $10 \%$ of the national income.

Still, the data suggest that even in rich nations a considerable share of welfare services can currently as well be provided by nonstate institutions. Yet this does not mean that we can reduce state-care without harming livability at least contemporarily. Non-state welfare provision has atropined in the welfare-states, hence sudden cuts in state-welfare can leave citizens without equivalent alternative.

\section{Implications for the Discussion on the Welfare-State}

In the rich nations, the welfare-state as such is hardly questioned. The current controversy is about the share of the state in the welfare provision. Conservatives tend to plea for a modest share, such as in the USA. Progressive mostly prefer a big share, such as in Sweden.

The results of this study show that these differences are largely irrelevant for the total livability of the country. Apparently the balance of positive and negative effects is equal for both options; at least in rich nations. Therefore, the discussion cannot be decided on the livability criterion.

Still, a choice must be made about the size of the welfare-state. That choice must now be based on other criteria than livability. Conservatives will stress 'economic competitiveness' and progressives 'social justice'. There is nothing wrong with that, but we must realize that the aim is then on competitiveness and justice for itself, not competitiveness and justice for the sake of livability. We must still make a choice, but what we choose is less relevant. 
In the poor nations the discussion is rather about some statewelfare or none at all. The data are less clear in this case, both because the observations are more limited and because the control for economic prosperity may have been too severe. Still, we must count with the possibility that developing nations can be equally livable without any state-welfare.

\section{Issues for Further Research}

\section{Effect in poor nations}

It is still possible that some state-welfare (rather than non at all) does add to livability in poor nations. The range of indicators considered is small in this case. In fact we had a only a sufficient number of cases for one indicator of livability (life-expectancy) and one indicator of state-welfare-effort (ILO index of expenditures). Moreover, the control for economic prosperity may have been too severe.

The problem of limited indicators is solvable in principle, though not easy in practice. Probably the indicators used for rich nations will become available for a sizable number of poor nations as well. The task is then to try again.

The problem of distinguishing between effects of economic prosperity and state-welfare can hardly be solved however, unless statisticians find out new methods for dealing with multi-collinearity.

\section{Contingencies}

As noted above, the effect of state-welfare-effort on livability may be contingent on situations. In that context it is worth noting that the data used here concern an era of relative smooth economic development and political stability. Possibly, state-welfare has an edge over its alternatives in times of turmoil. Such contingencies can be identified by comparing effects in different decades or by considering contrasting groups of nations.

\section{Separate welfare services?}

We have considered total state-welfare-effort. Policy makers are mostly more interested in the relative performance of the state in the production of separate welfare services; decisions are made on specific services, total welfare-effort is typically the unintended sum of such piecemeal decisions. The issue is certainly not irrelevant; states may do relatively good in the provision of old age pensions, 
and commercial insurance companies may perform better in the financing of health care. Though not easy, it is possible to estimate the degree of state-involvement in the production of specific welfare services in countries. The problem is rather in the output criterion. The differences at hand hare are probably too small to affect total livability of the country.

\section{Dispersion of happiness and health}

We have measured the livability of nations by the degree to which citizens live long and happily. For that purpose we considered the average level of life-satisfaction and life-expectancy. We did not consider dispersion around that level.

Though state involvement in the provision of welfare may not add to the level of livability of the country, it may still generate more equality in quality-of-life. In the typical welfare-states citizens may be about equally happy and healthy, whereas in other states great differences in well-being exist. If so, that would plea for high state involvement; now not for the sake of livability, but for the sake of equality.

For this purpose we have also examined the dispersion in appreciation-of-life and in length-of-life in nations. At first sight there is no difference in that respect either (Veenhoven, 1992; Veenhoven and Ouweneel, in preparation).

\section{CONCLUSION}

The welfare-state does not appear as a more livable society. This is clearly so for rich nations, among which much (rather than modest) state-welfare does not materialize in a longer or happier life of the average citizen. Probably the same is true for poor nations, among which little (rather than none) state-welfare does not seem to add to average length of life either.

Though there is no evidence for a positive effect of state-welfare, there is no evidence for a negative effect either. So neither the proponents of the welfare-state, nor its critics can claim victory.

Because the amount of state-welfare does not affect the livability of the country, the choice for much or modest welfare can be based on other grounds. 


\section{NOTES}

1 For a review of the discussion on the welfare state see i.a. Chelf (1992), Mishra (1984), Murray (1984), Off (1984), Wilding (1986), Ringen (1987) and Zapf (1994). The criterion of livability is mostly implicit in the discussion.

2 There is one outlier not shown in Figure 4. That is the case of Kuwait. Kuwait provided abundant state-welfare in the 1980's. Because Kuwait was immensely rich at that time, its welfare-expenditures were nevertheless low relative to the national income. Hence Kuwait scores low on the ILO index. The exceptional wealth of Kuwait distorts the analysis in another way as well; life-expectancy in Kuwait is low relative to its wealth. As a result Kuwait figures in isolation left under in Figure 4, and produces a positive correlation of residuals $(r=+0.31 ; p<$ 0.05 ). The case of Bahrein is similar. Therefore these two Gulf-states are left out.

3 This oval pattern of residuals is at least partly produced by the method of analysis used here. Residuals are deviations from a linear regression line. The relationship between life-expectancy and economic prosperity is non-linear however. It follows a convex curve, typical of a pattern of diminishing utility. The linear regression line cuts this curve at two points, before its bend and after. As a result the deviations are greater at the extremes and in the bend. This produces high residuals for very poor nations such as Gabon as well as for close-to-rich nations such as Sri Lanka. The relation between economic affluence and state-welare is also curved, but less so. Therefore, the pattern of oval rather than round.

4 For the entire nation-set we have only comparable data over a 20 year period.

5 The different indicators of state-welfare-effort produce at least similar non-relations with livability in rich nations. The analysis of the poor nations is exclusively based on one financial indicator (the ILO index)

6 Positive effects of state-welfare on economic growth are discussed in more detail in George and Wilding (1984).

\section{REFERENCES}

Alber, J.: 1988, Is there a crisis of the welfare state? Cross-national evidence from Europe, North America, and Japan', European Sociological Review 4, pp. $181-183$.

Borenstein, L.: 1993, Comparative GDP levels, Physical Indicators, phase III (United Nations: New York).

Chelf, C. P.: 1992, Controversial Issues in Social Welfare Policy; Government and the Pursuit of Happiness (Sage: London).

Douglas, J. D.: 1989, The Myth of the Welfare State (Transaction Publisher: New Brunswick).

Esping-Anderson, G.: 1990, The Three World of Welfare Capitalism (Polity Press: Cambridge).

Estes, R.: 1984, The Social Progress of Nations (Preager: New York).

George, V. and Wilding, P.: 1984, The Impact of Social Policy (Routledge: London).

Gordon, M. S.: 1988, Social Security Policies in Industrial Countries (Cambridge University Press: New York). 
Hayek, F. A.: 1946, The Road to Serfdom (Routledge: London).

ILO: 1988, 'The costs of social security: 12th international inquiry 1981-1983', International Labour Organization: Geneva.

IMF: 1986, Manual on Government Finance Statistics (International Monetary Fund: Washington).

Mishra, R.: 1984, The Welfare State in Crisis (Harvester: Brighton).

Murray, G.: 1984, Loosing Ground: American Social Policy 1950-1980 (Basic Books: New York).

Naroll, R.: 1983, The Moral Order: An Introduction to the Human Situation (Sage: New York).

OECD: 1990, Social Expenditures 1960-1990 (Organization for Economic Development: Paris).

Ouweneel, P. and R. Veenhoven: 1990, 'Differences in happiness across nations: Cultural bias or societal quality?' in: N. Bleichrotdt and P. J. Drenth (eds.), Contemporary Issues in Cross-Cultural Psychology (Swets \& Zeitlinger: Amsterdam), pp. 168-184.

Summers, R. and A. Heston: 1988, 'A new set of international comparisons of real product and price level estimates for 130 countries, $1950-1985^{\prime}$ ', National Income and Wealth 34, pp. 1-25.

UNDP: 1990, World Development Report (Oxford University Press: London).

Veenhoven, R.: 1984, Conditions of Happiness (Kluwer Academic: Dordrecht).

Veenhoven, R.: 1986, 'Cultural bias in rating of perceived life quality', Social Indicator Research 19, pp. 329-334.

Veenhoven, R.: 1991, 'Is happiness relative?', Social Indicators Research 24, pp. 1-34.

Veenhoven, R.: 1993, 'Happiness in nations: subjective appreciation of life in 56 nations 1946-1992', RISBO, Erasmus University, Rotterdam (electronically published on ftp.eur.nl pub $\backslash$ database.happiness $\backslash$ nations).

Veenhoven, R.: 1994, 'Is happiness a trait? Tests of the theory that a better society does not make people an happier', Social Indicators Research 32, pp. 101-160. Veenhoven, R.: 1995, 'The cross-national pattern of happiness: Tests of predications implied in three theories of happines', Social Indicators Research 34, pp. 33-68.

Veenhoven, R. and P. Ouweneel: 'Equality in the welfare-state: dispersion in satisfaction-with-life and length-of-life in nations varying in state-welfareeffect', (in preparation).

WHO: 1988, World Health Statistics Annual (World Health Organization: Geneva).

Zapf: 1994, Modernisierung, Wohlfahrtsentwicklung und Transformation: Soziologische Aufsätze 1987-1994 (Edition Sigma, Berlin).

Department of Sociology,

Erasmus University Rotterdam, P.O. Box 1738, 3000 DR Rotterdam, The Netherlands 


\section{APPENDIX 1}

Datamatrix: Level of livability and state welfare in the 1980's

Livability:

\begin{tabular}{|l|l|l|l|l|l|l|l|}
\hline Nations & \\
\hline$A z$ & $\mathrm{Dz}$ & $\mathrm{nNr}$ & $\mathrm{aA}$ & $\mathrm{aUS}$ & $\mathrm{A}$ & $\mathrm{B}$ & $\mathrm{as}$ \\
\hline
\end{tabular}

\begin{tabular}{|c|c|c|c|c|c|c|c|c|c|}
\hline \multirow[t]{5}{*}{ Appreciation of iffe } & $\begin{array}{l}\text { Happiness } \pm 19980 \\
\text { (Veenhover, } 1993 \text { ) }\end{array}$ & * & - & * & - & 7.75 & 6.68 & $*$ & - \\
\hline & Change happiress $1975-85$ & - & - & - & - & .03 & - & $\therefore$ & . \\
\hline & $\begin{array}{l}\text { Life saximfiaction } \pm 10 \text { so } \\
\text { (Veenhoven, 1993) }\end{array}$ & - & - & - & - & 7,57 & 7.10 & - & - \\
\hline & $\begin{array}{l}\text {-Change tije satisfaction } \\
1950-1980\end{array}$ & * & $=$ & - & $=$ & +29 & $=$ & - & - \\
\hline & $\begin{array}{l}\text {-Change life satisfactions } \\
\text { 1975-85 }\end{array}$ & - & - & $*$ & - & * &. .23 & - & + \\
\hline \multirow[t]{3}{*}{ Length of life } & $\begin{array}{l}\text { Life equectation }=1950 \\
\text { (WhO, (994) }\end{array}$ & $2^{71}$ & 60.0 & 624 & 60.1 & 75.1 & 73.0 & 31.6 & 66.7 \\
\hline & $\begin{array}{l}\text { Change lifte-epectancy } \\
1965-85 \text { (UN, 2972-9I) }\end{array}$ & - & $\cdot$ & * & - & 4.8 & 7.3 & . & - \\
\hline & $\begin{array}{l}\text { Change bifwepectancy } \\
\text { 1975-85 (tN, 1970-91) }\end{array}$ & - & - & - & . & 22 & 4.3 & * & - \\
\hline
\end{tabular}

Indicators of state welfare:

-legal indicators

\begin{tabular}{|c|c|c|c|c|c|c|c|c|c|}
\hline History & $\begin{array}{l}\text { Welfare inder } \\
\text { (Eses, 19sin) }\end{array}$ & 9 & 13 & - & 12 & 22 & 28 & . & . \\
\hline Coverage & $\begin{array}{l}\text { Decommadification index } \\
\text { (Eping-Anderson, } 1990) \text { ) }\end{array}$ & - & - & . & - & 13.0 & 31.1 & * & - \\
\hline
\end{tabular}

\begin{tabular}{|c|c|c|c|c|c|c|c|c|c|}
\hline \multirow[t]{6}{*}{ Social security $\%$ of GDP } & $\begin{array}{l}O E C D, 1980 \\
(O E C D, 1986)\end{array}$ & * & - & - & - & 86 & 19.0 & - & - \\
\hline & $\begin{array}{l}\text { Modified OECD } 1980 \\
\text { (Gordom, 1988) }\end{array}$ & $\cdot$ & - & - & - & 9.8 & 16.7 & . & - \\
\hline & $1501980(120,1088)$ & $=$ & $=$ & 0.9 & 9.3 & 10.7 & 225 & 0.7 & 0.5 \\
\hline & -Change ItLO $1965-85$ & - & - & . & - & 1.7 & 75 & 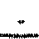 & - \\
\hline & - Change 11LO 1975-85 & - & - & ш & - & -0.3 & 5.0 &. & - \\
\hline & $\begin{array}{l}\text { LAF } 1980 \\
{[\text { (MF, } 1983-87-88)}\end{array}$ & - & - & - & $=$ & 83 & 18.2 & * & - \\
\hline \multirow[t]{3}{*}{ Govemtnent expenditures } & $\begin{array}{l}\text { Expenditures } p / c 1980 \\
(M F, 1988)\end{array}$ & - & - & - & - & 30.1 & 27.8 & - & $\cdot$ \\
\hline & $\begin{array}{l}\text { Disbursements \% of GDP } \\
1980 \text { (OECD, 1986) }\end{array}$ & $\cdot$ & $=$ & - & - & 29.8 & 42.8 & m & - \\
\hline & $\begin{array}{l}\text { Consumption \% of GDP } \\
1980 \text { (OECD, 1986) }\end{array}$ & - & - & . & - & 16.0 & 18.0 & - & $\cdot$ \\
\hline
\end{tabular}




\begin{tabular}{|l|c|c|c|c|c|c|c|c|c|c|c|c|c|c|}
\hline \multicolumn{10}{|c|}{ Nations } \\
\hline BRN & BD & BDS & B & BH & DY & RB & BR & BO & 8U & RU & RCA & CR & CAM & CDN \\
\hline
\end{tabular}

\begin{tabular}{|c|c|c|c|c|c|c|c|c|c|c|c|c|c|c|}
\hline & - & - & 7.57 & - & $*$ & - & 7.22 & - & - & - & - & - & - & 7.76 \\
\hline$\cdot$ & - & - & -45 & - & - & - & - & - & - & - & - & - & - & .33 \\
\hline- & - & - & 7.07 & - & - & - & 7.03 & - & - & - & - & - & - & 7.60 \\
\hline- & - & - & -.7 & - & - & - & - & - & - & - & - & - & - & -.10 \\
\hline 67.4 & 54.9 & 69.9 & 73.4 & 49.0 & 44.1 & 53.0 & 63.5 & 71.0 & 59.3 & 41.5 & 34.5 & 68.4 & 48.1 & 75.2 \\
\hline- & - & - & 2.8 & - & - & 9.0 & - & - & - & - & - & 11.3 & - & 4.4 \\
\hline- & - & - & 2.4 & $*$ & - & 4.3 & - & - & - & - & - & 6.3 & - & 3.5 \\
\hline
\end{tabular}

\begin{tabular}{|c|c|c|c|c|c|c|c|c|c|c|c|c|c|c|}
\hline- & - & - & 25 & $*$ & 4 & 8 & 16 & 20 & 3 & 1 & 5 & 6 & 4 & 16 \\
\hline- & - & - & 324 & $*$ & $*$ & - & - & - & - & - & - & - & - & 220 \\
\hline
\end{tabular}

\begin{tabular}{|c|c|c|c|c|c|c|c|c|c|c|c|c|c|c|}
\hline- & - & - & 20.9 & $\cdot$ & - & - & - & - & - & - & - & - & - & 10.1 \\
\hline- & - & - & 20.6 & - & - & - & - & $\cdot$ & - & - & - & - & - & 123 \\
\hline 0.3 & 0.01 & 22 & 25.9 & 1.1 & 1.9 & 29 & 4.8 & 12.2 & 0.1 & 0.3 & 0.9 & 7.1 & 0.5 & 14.2 \\
\hline- & - & - & 10.3 & - & - & -1.2 & - & - & - & - & - & 5.1 & - & 6.8 \\
\hline- & - & - & 2.4 & - & - & -1.2 & - & - & - & - & - & 2.3 & - & 2.4 \\
\hline- & - & - & 22.3 & - & - & - & - & - & - & - & - & - & - & 10.8 \\
\hline- & - & - & 48.1 & - & - & - & - & - & - & - & - & - & - & 37.8 \\
\hline- & - & - & 47.5 & - & - & - & - & - & - & - & - & - & - & 37.8 \\
\hline- & - & - & 17.9 & - & - & - & - & - & - & - & - & - & - & 19.5 \\
\hline
\end{tabular}




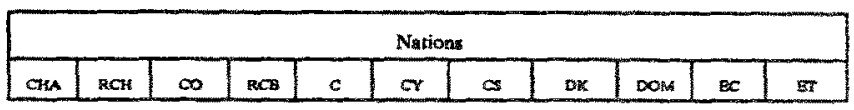

\begin{tabular}{|c|c|c|c|c|c|c|c|c|c|c|c|}
\hline $\begin{array}{l}\text { Happines } \pm 1980 \\
\text { (Veenthoven, 1993) }\end{array}$ & $*$ & - & - & - & - & $\cdots$ & - & $7.6 \%$ & - & - & \% \\
\hline -Change happiness $1975-85$ & - & - & + & - & + & 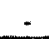 & - & -.19 & - & - & - \\
\hline $\begin{array}{l}\text { Life satisfaccion } \\
\text { (Venthoven, 1993) }\end{array}$ & * & $=$ & - & - & - & - & - & 7.92 & . & $=$ & * \\
\hline $\begin{array}{l}\text {-Change Life sarisfaction } \\
\text { 1950-i } 1980\end{array}$ & - & - & $*$ & - & - & ж & - & $a$ & - &. & m \\
\hline $\begin{array}{l}\text { Change life satisfaction } \\
1975.55\end{array}$ & . & - & - & - & - & * & - & .48 & - & - & - \\
\hline $\begin{array}{l}\text { Life expectation }=19890 \\
\text { (WHO, 1984) }\end{array}$ & 320 & 645 & 637 & 46.5 & 73.2 & 742 & 70.7 & 74.9 & 57.9 & 60.7 & 527 \\
\hline $\begin{array}{l}\text { - Change life-epectancy } \\
196585 \text { (UN, 1979.91) }\end{array}$ & - & 13.9 & $1 \geq 3$ & - & - & 6.6 & - & 22 & - & - & - \\
\hline $\begin{array}{l}\text { Change life-eqpectancy } \\
1975-85(U N, 1972-9)\end{array}$ & - & 9.0 & 6.4 & - & - & 4.4 & - & 0.7 & - & - & - \\
\hline
\end{tabular}

\begin{tabular}{|c|c|c|c|c|c|c|c|c|c|c|c|}
\hline $\begin{array}{l}\text { Welfare index } \\
\text { (Extes, } 19884)\end{array}$ & 5 & 200 & 11 & - & 11 & 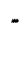 & 24 & 28 & 5 & 10 & 5 \\
\hline $\begin{array}{l}\text { Dexommadification index } \\
\text { (Exping Anderson, } 1990 \text { ) }\end{array}$ & * & - & $=$ & - & - & * & - & : 1 & - & - & - \\
\hline
\end{tabular}

\begin{tabular}{|c|c|c|c|c|c|c|c|c|c|c|c|}
\hline $\begin{array}{l}O E C D 1980 \\
\text { (OECD, 1986) }\end{array}$ & * & - & - & - & - & - & - & 16.6 & - & . & . \\
\hline $\begin{array}{l}\text { Modifized OECD } 1980 \\
\text { (Gordon, 1988) }\end{array}$ & - & $=$ & - & - & * & - & * & 25.0 & - & . & - \\
\hline ILO 1980 (ILO, 1988) & 0.4 & 10.7 & 28 & 0.8 & 11.7 & 3.7 & 18.9 & 29.9 & 0.8 & 29 & - \\
\hline -Change IILO 1965-85 & - & 13.9 & 0.9 & . & - & 25 & - & 13.7 & - & . & - \\
\hline Change 120 197585 & - & 25 & -1.1 & - & - & -22 & - & 5.7 & - & * & * \\
\hline $\begin{array}{l}\text { IMF } 1980 \\
(L M F, 1983-87-88)\end{array}$ & - & - & - & - & $=$ & - & - & 24.6 & - & - & - \\
\hline $\begin{array}{l}\text { Expenditures } P / c 1980 \\
(I M F, L 983)\end{array}$ & * & $=$ & * & - & - & - & - & 525 & - & $=$ & - \\
\hline $\begin{array}{l}\text { Disbursemenus \% of GDP } \\
\text { (9980 (OECD, 1996) }\end{array}$ & - & - & - & * & . & - & - & $\$ 22$ & . & - & . \\
\hline $\begin{array}{l}\text { Consumprion \% of GDP } \\
1980 \text { (OECD, } 1986 \text { ) }\end{array}$ & - & $=$ & - & - & - & - & - & 36.7 & - & - & - \\
\hline
\end{tabular}




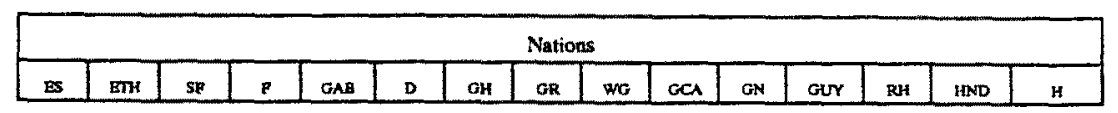

\begin{tabular}{|c|c|c|c|c|c|c|c|c|c|c|c|c|c|c|}
\hline- & - & - & 7.24 & - & 6.98 & - & 5.61 & - & - & - & - & - & - & - \\
\hline- & - & - & .11 & - & 21 & - & - & - & - & - & - & - & - & - \\
\hline- & - & - & 6.29 & - & 6.94 & - & 5.0 & - & - & - & - & - & - & - \\
\hline- & - & - & .65 & - & 55 & - & - & - & - & - & - & - & - & - \\
\hline- & - & - & -.37 & - & -.05 & - & - & - & - & - & - & - & - & - \\
\hline 585 & 42.9 & 73.6 & 75.0 & 35.0 & 73.9 & 520 & 76.0 & 62.9 & 54.6 & 40.3 & 61.1 & 52.8 & 55.2 & 7.1 \\
\hline-1.2 & - & 5.6 & 4.6 & - & 4.6 & - & 5.2 & - & 3.3 & - & 88 & - & - & - \\
\hline- & - & 2.9 & 3.2 & - & 3.5 & - & 0.1 & - & 2.7 & - & - & - & - & - \\
\hline
\end{tabular}

\begin{tabular}{|c|c|c|c|c|c|c|c|c|c|c|c|c|c|c|}
\hline 6 & -1 & 18 & 26 & - & 29 & 1 & 16 & - & 2 & 6 & - & 0 & 1 & 2 \\
\hline- & - & 29.2 & 27.5 & - & 27.7 & - & - & - & - & - & - & - & - & - \\
\hline
\end{tabular}

\begin{tabular}{|c|c|c|c|c|c|c|c|c|c|c|c|c|c|c|}
\hline- & - & 8.7 & 23.2 & - & 16.5 & - & 9.2 & - & - & - & - & - & $\cdot$ & - \\
\hline- & - & 15.0 & 22.7 & - & 19.4 & - & 8.9 & - & - & - & - & - & - & - \\
\hline 1.7 & 1.1 & 18.0 & 26.7 & 2.0 & 24.0 & - & 122 & 1.7 & 12 & - & 1.3 & - & 0.8 & 18.3 \\
\hline-0.9 & - & 11.5 & 13.1 & - & 72 & - & 10.3 & - & -1.0 & - & -25 & - & - & - \\
\hline-2.0 & - & 6.4 & 4.8 & - & 0.1 & - & 8.7 & - & -1.0 & - & -0.1 & - & - & - \\
\hline- & - & 8.5 & 20.0 & - & 20.5 & - & 11.1 & - & - & - & - & - & - & - \\
\hline- & - & - & 42.9 & - & 42.9 & - & 26.0 & - & - & - & - & - & - & - \\
\hline- & - & 32.6 & 43.0 & - & 42.9 & - & 30.5 & - & - & - & - & - & - & - \\
\hline- & - & 18.1 & 15.2 & - & 20.1 & - & 16.4 & - & - & - & - & - & - & - \\
\hline
\end{tabular}




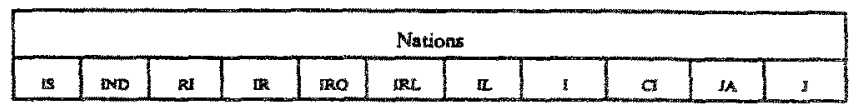

\begin{tabular}{|c|c|c|c|c|c|c|c|c|c|c|c|}
\hline $\begin{array}{l}\text { Happiness =1980 } \\
\text { (Veenhoven, 1993) }\end{array}$ & 7.84 & 5.16 & - & $=$ & - & 7.82 & - & 6.47 & $*$ & - & 6.94 \\
\hline -Change hapqiness $1975-85$ & - & - & - & - & $\rightarrow$ & $\$ 8$ & - & $A B$ & - & - & .72 \\
\hline $\begin{array}{l}\text { Life satisfaction } \\
\text { (Veenhoven, 1993) }\end{array}$ & 7,88 & 3.35 & - & - & - & 758 & - & 6.24 & 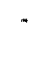 & $=$ & 6.20 \\
\hline $\begin{array}{l}\text { - Change life sasisfaction } \\
\text { 1950 1080 }\end{array}$ & . & - & - & * & * & - & - & .14 & - & $=$ & $=$ \\
\hline $\begin{array}{l}\text { Change life satisfaction } \\
1975-\$ 5\end{array}$ & - & $*$ & $=$ & - & - & -.64 & - & .25 & - & $=$ & .37 \\
\hline $\begin{array}{l}\text { Life expectation }=1980 \\
\text { (WHO, 1984) }\end{array}$ & 76.7 & 55.4 & $\$ 3.6$ & 55.4 & 624 & 723 & 73.8 & 74.4 & 47.1 & 64.7 & 76.1 \\
\hline $\begin{array}{l}\text {-Change lifemexpectoricy } \\
195585 \text { (ON, 2979-91) }\end{array}$ & 3.7 & . & - & $=$ & - & 22 & 3.0 & 4.7 & - & 9.4 & 8.1 \\
\hline 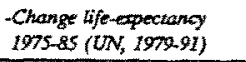 & 0.9 & - & * & $=$ & - & 1.7 & 32 & 32 & * & - & 40 \\
\hline
\end{tabular}

\begin{tabular}{|c|c|c|c|c|c|c|c|c|c|c|c|}
\hline $\begin{array}{l}\text { Welfare index } \\
\text { (Estes, 7984) }\end{array}$ & - & 6 & 2 & 9 & 5 & 25 & 7 & 26 & 5 & 3 & 12 \\
\hline $\begin{array}{l}\text { Decommodification index } \\
\text { (Esping-Anderson, 1990) }\end{array}$ & - & - & $=$ & - & $=$ & 23.3 & - & 24.1 & " & - & 27.1 \\
\hline
\end{tabular}

\begin{tabular}{|c|c|c|c|c|c|c|c|c|c|c|c|}
\hline $\begin{array}{l}O E C D 1980 \\
\text { (OECD, 1986) }\end{array}$ & 4.5 & - & - & - & * & 126 & - & 15.8 & * & - & 10.2 \\
\hline $\begin{array}{l}\text { Modified OECD } 1980 \\
\text { (Gordor, 1989) }\end{array}$ & - & * & - & - & - & 18.4 & $=$ & 13.8 & - & - & 7.7 \\
\hline ILO 1980 (11LO, 1988) & 6.9 & 1.7 & 0.01 & 1.1 & $*$ & 20.1 & 15.2 & $21 s$ & 0.6 & 1.4 & 112 \\
\hline Change $11001965-85$ & 0.1 & + & - & 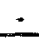 & $=$ & 125 & 9.2 & -3.6 & $\therefore$ & -1.8 & 8.6 \\
\hline -Change 1100 1975-85 & -29 & - & $=$ & - & - & 3.8 & 3.2 & -8.0 & 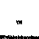 & $-2 \mathrm{~B}$ & 28 \\
\hline $\begin{array}{l}\text { LMF } 1980 \\
(I N F, 1989-87-88)\end{array}$ & 4.7 & 1.6 & - & - & - & 13.2 & - & 12.1 & 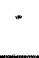 & - & 11.1 \\
\hline $\begin{array}{l}\text { Expenditures } p / c 1950 \\
(I M F, 1088)\end{array}$ & $*$ & * & - & * & * & 49.2 & - & 44.5 & - & $\cdot$ & 29.5 \\
\hline $\begin{array}{l}\text { Dishursertents \% of GDP } \\
1980 \text { (OECD, 1986) }\end{array}$ & 25.0 & - & $=$ & . & - & $4 S .1$ & - & 415 & - & - & 25.0 \\
\hline $\begin{array}{l}\text { Consumption \% of GDP } \\
1980 \text { (OECD, 1986) }\end{array}$ & 16.4 & * & - & - & - & 199 & * & 16.4 & • & . & 9.8 \\
\hline
\end{tabular}




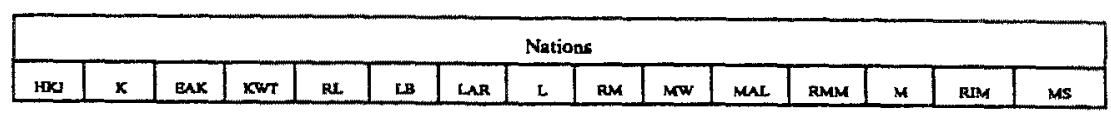

\begin{tabular}{|c|c|c|c|c|c|c|c|c|c|c|c|c|c|c|}
\hline- & - & - & - & - & - & - & 7.11 & - & - & - & - & - & - & - \\
\hline- & - & - & - & - & - & - & .43 & - & - & - & - & - & - & - \\
\hline- & - & - & - & - & - & - & 724 & - & - & - & - & - & - & - \\
\hline- & - & - & - & - & - & - & - & - & - & - & - & - & - & - \\
\hline- & - & - & - & - & - & - & .17 & - & - & - & - & - & - & - \\
\hline 67.8 & 435 & 49.1 & 69.0 & 65.1 & 44.9 & 58.0 & 72.4 & 37.9 & 39.7 & 70.1 & 48.3 & 72. & 44.0 & 63.0 \\
\hline- & - & - & - & - & - & - & 5.2 & - & - & - & - & - & - & - \\
\hline- & - & - & - & - & - & - & 3.7 & - & - & - & - & - & - & - \\
\hline
\end{tabular}

\begin{tabular}{|c|c|c|c|c|c|c|c|c|c|c|c|c|c|c|}
\hline 3 & 6 & 1 & - & 5 & -1 & 1 & - & 6 & 1 & 4 & 5 & - & - & - \\
\hline$\cdot$ & - & - & - & - & - & - & - & - & - & - & - & - & - & - \\
\hline
\end{tabular}

\begin{tabular}{|c|c|c|c|c|c|c|c|c|c|c|c|c|c|c|}
\hline- & - & - & - & - & - & - & 22. & - & - & - & - & - & - & - \\
\hline- & - & - & - & - & - & - & - & - & - & - & - & - & - & - \\
\hline 1.0 & - & 0.1 & 0.8 & - & 0.1 & - & 245 & 0.6 & - & 20 & 0.8 & 11.1 & 2.0 & 19 \\
\hline- & - & - & - & - & $\cdot$ & - & 83 & - & - & - & - & 10.0 & - & - \\
\hline- & - & - & - & - & - & - & 23 & - & - & - & - & 7.7 & - & - \\
\hline- & - & - & - & - & - & - & - & - & - & - & - & - & - & - \\
\hline- & - & - & - & - & - & - & - & - & - & - & - & - & - & - \\
\hline- & - & - & - & - & - & - & 46.1 & - & - & - & - & - & - & - \\
\hline & - & - & - & - & - & - & 18.7 & - & - & - & - & - & - & - \\
\hline
\end{tabular}




\begin{tabular}{|l|l|l|l|l|l|l|l|l|l|l|}
\hline Nations \\
\hline$M$ & $M A$ & $N Z$ & $N E$ & $\mathrm{NE}$ & $\mathrm{NKC}$ & $\mathrm{NN}$ & $\mathrm{WAN}$ & $\mathrm{N}$ & $\mathrm{PH}$ & $\mathrm{PA}$ \\
\hline
\end{tabular}

\begin{tabular}{|c|c|c|c|c|c|c|c|c|c|c|c|}
\hline $\begin{array}{l}\text { Happiness } \pm 1980 \\
\text { (Veenhwer, 1993) }\end{array}$ & 6.31 & - & - & - & 7.63 & - & + & - & 7.45 & - & $=$ \\
\hline -Change happines $1975-85$ & - & $=$ & $=$ & 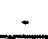 & 30 & $=$ & - & - & $=$ & - & - \\
\hline $\begin{array}{l}\text { Life satisfaction } \\
\text { (Veenhover, 1999) }\end{array}$ & 432 & - & - & - & 7.46 & $=$ & - & $=$ & 7.67 & - & - \\
\hline $\begin{array}{l}\text {-Change life satisfaction } \\
\text { 1950-1980 }\end{array}$ & - & - & - & $\ldots$ & .74 & - & - & - & .10 & . & - \\
\hline $\begin{array}{l}\text {-Change life sadiufiaction } \\
\text { 1975-85 }\end{array}$ & - & - & - & $*$ & -.04 & - & - & - & * & - & - \\
\hline $\begin{array}{l}\text { Life eppectation }=1080 \\
(\mathrm{~W} / \mathrm{HO}, 1984)\end{array}$ & 64.1 & 580 & 73.8 & 45.9 & 76.3 & 59.9 & 425 & 370 & 76.3 & 59.1 & 7.1 \\
\hline $\begin{array}{l}\text {-Change tffe-opectancy } \\
1965-85 \text { (UN, } 1970.91)\end{array}$ & $=$ & 4 & 3.0 & $=$ & 28 & - & - & $=$ & 22 & - & 128 \\
\hline $\begin{array}{l}\text { Change the-eqpectancy } \\
\text { 1975-8S (UN, 1979-91) }\end{array}$ & $=$ & 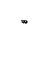 & 26 & . & 18 & . & - & - & 12 & - & 62 \\
\hline
\end{tabular}

\begin{tabular}{|l|c|c|c|c|c|c|c|c|c|c|c|}
\hline $\begin{array}{l}\text { Welfare indes } \\
\text { (Estes, 1984) }\end{array}$ & 5 & 9 & 25 & -1 & 25 & 3 & 2 & 1 & 24 & 3 & 7 \\
\hline $\begin{array}{l}\text { Decommadification inder } \\
\text { (Esping-Anderson, } 2990)\end{array}$ & - & - & - & - & 324 & - & - & - & 33.3 & - & - \\
\hline
\end{tabular}

\begin{tabular}{|c|c|c|c|c|c|c|c|c|c|c|c|}
\hline $\begin{array}{l}\text { OECD } 1980 \\
(O E C D, 1980)\end{array}$ & $=$ & - & - & - & 23.9 & - & . & - & 14,4 & . & - \\
\hline $\begin{array}{l}\text { Modified OECD } 19800 \\
\text { (Gordon, 1988) }\end{array}$ & - & $=$ & - & * & 24.2 & - & - & - & 18.8 & . & - \\
\hline$\not 201980(120,1988)$ & 27 & 1.2 & 16.6 & - & 283 & 23 & 0.3 & 0.02 & 202 & 05 & 5.9 \\
\hline - Change $\pi O 1965-85$ & - & - & 65 & $=$ & 13.6 & $=$ & - & $=$ & $\$ 7.4$ & $\dot{-}$ & 20 \\
\hline - Change ILO 1975-8s & 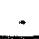 & - & 35 & - & 3.6 & - & - & - & 9.8 & 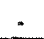 & 0.5 \\
\hline $\begin{array}{l}I M F 1980 \\
(I M F, 1983-87-88)\end{array}$ & - & * & - & - & 21.4 & - & - & - & 125 & * & - \\
\hline $\begin{array}{l}\text { Expenditures } p / c 1980 \\
\left(2 M F_{3}, 1988\right)\end{array}$ & - & $=$ & $=$ & - & $\$ 4.2$ & * & - & - & 45.2 & - & * \\
\hline $\begin{array}{l}\text { Disbursements \% of GDP } \\
1980(O E C D, 1986)\end{array}$ & . & - & * & - & 520 & - & - & * & 44.8 & $*$ &. \\
\hline $\begin{array}{l}\text { Consumption \% of GDP } \\
1980 \text { (OECD, } 1986)\end{array}$ & - & . & - & $m$ & 17.9 & - & - & - & 18.8 & - & - \\
\hline
\end{tabular}




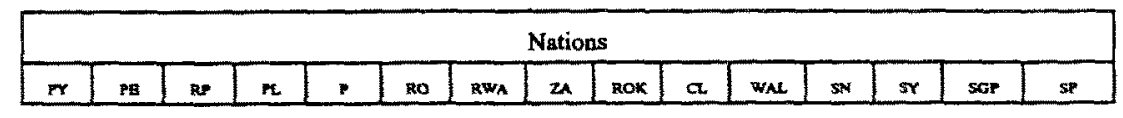

\begin{tabular}{|c|c|c|c|c|c|c|c|c|c|c|c|c|c|c|}
\hline - & - & - & - & 620 & * & - & 7,03 & 6.21 & - & - & - & . & 7.24 & " \\
\hline * & - & - & $=$ & * & - & $=$ & - & $=$ & - & - & $=$ & * & - & . \\
\hline - & - & - & - & 6.74 & . & - & 6.43 & 5.50 & - & - & - & - & 7.12 & * \\
\hline " & - & - & - & - & . & - & * & - & - & - & - & - & $=$ & * \\
\hline - & $=$ & - & - & - &. & . & - & $=$ & - & - & - & . & - & * \\
\hline 65.2 & 58.7 & 64.6 & $x .7$ & 71.8 & 69.8 & 46.4 & 53.5 & 65.9 & 69.8 & 34.0 & 43.3 & 69.9 & 71.4 & 429 \\
\hline . & $=$ & $=$ & $=$ & 83 & - & * & - & - & - & * & $=$ & - & $=$ & - \\
\hline . & - & - & - & 3.1 & . & - & - & - & - & - & - & - & - & - \\
\hline
\end{tabular}

\begin{tabular}{|c|c|c|c|c|c|c|c|c|c|c|c|c|c|c|}
\hline 8 & 9 & 4 & 18 & 13 & 17 & 2 & 18 & 0 & 5 & 1 & 6 & $*$ & 4 & 1 \\
\hline- & $*$ & - & - & - & - & - & - & - & - & $*$ & - & - & - & - \\
\hline
\end{tabular}

\begin{tabular}{|c|c|c|c|c|c|c|c|c|c|c|c|c|c|c|}
\hline - & - & - & - & 10.4 & - & $=$ & $*$ & - & - & - & - & - & $=$ & - \\
\hline - & - & - & - & $=$ & $=$ & - & - & - & - & - & - & - & - & - \\
\hline - & 22 & 0.7 & $=$ & 9.7 & 17 & 0.1 & $=$ & - & 1.7 & - & 0.7 & 21 & 3.8 & - \\
\hline$m$ & . & $\sigma$ & - & 4.8 & - & - & - & - & $\cdot$ & - & - & - & * & - \\
\hline - & - & - & - & -1.0 & - & . & - & $=$ & - & $=$ & - & + & $=$ & 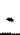 \\
\hline * & - & - & - & 10.2 & - & - & - & - & - & $\cdot$ & - & - & 15 & " \\
\hline- & - & - & $=$ & 36.6 & - & - & * & - & - & - & - & - & - & * \\
\hline$*$ & $=$ & - & - & 33.2 & * & - & - & - & - & - & - & - & " & - \\
\hline - & - & - & - & 14.0 & - & - & - & - & - & - & - & $\cdots$ & - & - \\
\hline
\end{tabular}




\begin{tabular}{|c|c|c|c|c|c|c|c|c|c|c|}
\hline \multicolumn{11}{|c|}{ Nations } \\
\hline \& & sun & SME & $s$ & $\mathrm{CH}$ & $5 \gamma \mathrm{R}$ & EAT & $\pi$ & To & $\mathrm{TT}$ & $\mathrm{W}$ \\
\hline
\end{tabular}

\begin{tabular}{|c|c|c|c|c|c|c|c|c|c|c|c|}
\hline $\begin{array}{l}\text { Happiness } \pm 1980 \\
\text { (Veumhowern 1993) }\end{array}$ & 6.84 & - & - & 7.62 & 699 & * & $\cdot$ & - & - & - & - \\
\hline - Change happiness 1975-85 & - & $=$ & $=$ & - & - & - & - & $\approx$ & - & . & - \\
\hline $\begin{array}{l}\text { Life sanisfaction } \\
\text { (Vetrhoven, 1993) }\end{array}$ & 6.22 & $=$ & $*$ & 7.80 & 8.60 & * & - & - & - & - & - \\
\hline $\begin{array}{l}\text { Change life satisfaction } \\
1050-1980\end{array}$ & $*$ & - & - & .42 & - & - & - & - & - & . & - \\
\hline $\begin{array}{l}\text { - Change life satisfaction } \\
1975-85\end{array}$ & * & - & - & - & - & - & - & - & . & - & * \\
\hline $\begin{array}{l}\text { Life onpectation } \pm 1900 \\
\text { (WHO, } 1984 \text { ) }\end{array}$ & 75.6 & 47.8 & 64.6 & 76.2 & 76.2 & 64.3 & 52.0 & 60.5 & 35.2 & 693 & 50.6 \\
\hline $\begin{array}{l}\text { Chantge tife-equectancy } \\
1965-85 \text { (UN, 1979-91) }\end{array}$ & - & - & * & 3.5 & 5.2 & 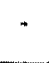 & - & - & 17.9 & 5.1 & " \\
\hline $\begin{array}{l}\text { Charge life-epectancy } \\
1975 \text { \&5 (UN, 1979-91) }\end{array}$ & * & - & - & 25 & 3.5 & - & - & * & 9.5 & 32 & " \\
\hline
\end{tabular}

\begin{tabular}{|l|c|c|c|c|c|c|c|c|c|c|c|}
\hline $\begin{array}{l}\text { Welfure index } \\
\text { (Ester, 2084) }\end{array}$ & 21 & 4 & - & 23 & 19 & 1 & 2 & 1 & 2 & 3 & 7 \\
\hline $\begin{array}{l}\text { Decommadification index } \\
\text { (Esping Anderson, 2990) }\end{array}$ & $\cdot$ & - & - & 39.1 & 29.8 & $*$ & - & - & - & - & - \\
\hline
\end{tabular}

\begin{tabular}{|c|c|c|c|c|c|c|c|c|c|c|c|}
\hline $\begin{array}{l}O E C D, 1980 \\
\text { (OECD, 1986) }\end{array}$ & 15.0 & - & * & 17.8 & 127 & . & - & - & - & - & - \\
\hline $\begin{array}{l}\text { Modifed OECD t980 } \\
\text { (Gordom, 1988) }\end{array}$ & - & - & - & 28.6 & 12.0 & - & * & - & * & - & . \\
\hline ILO 1980 (ILO, 1988) & 16.0 & 0.1 & 21 & 31.9 & 13.7 & - & 0.3 & 5.0 & 1.0 & 1.4 & - \\
\hline Change LOO 1965-85 & - & $\therefore$ & - & 17.1 & 6.2 & $*$ & - & - & .12 & -1.1 & - \\
\hline Change $11.01975-85$ & - & - & - & 5.7 & -0.4 & - & - & - & 0.6 & 0.8 & - \\
\hline $\begin{array}{l}\text { IMF } 1980 \\
\left(I M F_{1}, 1983-87-88\right)\end{array}$ & 16.1 & - & - & 21.8 & 11.9 & $*$ & - & - & $=$ & - & - \\
\hline $\begin{array}{l}\text { Expendinures } p / c 1980 \\
(I M F, 1988)\end{array}$ & 31.0 & - & $*$ & 56.9 & 26.3 & w. & * & * & - & - & - \\
\hline $\begin{array}{l}\text { Disbumements \% of GDP } \\
1980(O E C D, 1886)\end{array}$ & 29.2 & * & + & 56.8 & 29.3 & - & - & - & - & * & . \\
\hline $\begin{array}{l}\text { Cansumption \% of GDP } \\
1980 \text { (OECD, 2986) }\end{array}$ & 115 & - & - & 28.8 & 12.7 & * & - & - & - & - & - \\
\hline
\end{tabular}




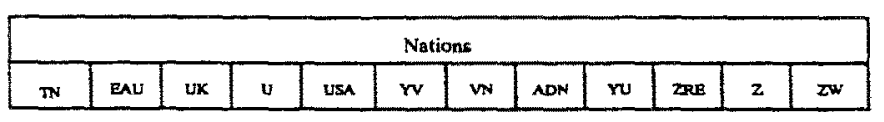

\begin{tabular}{|c|c|c|c|c|c|c|c|c|c|c|c|}
\hline$\cdot$ & $*$ & 7.74 & - & 755 & - & - & - & - & - & - & - \\
\hline- & - & 54 & - & -.05 & - & - & - & - & - & - & - \\
\hline- & - & 7.41 & - & 6.94 & - & $*$ & - & - & - & - & - \\
\hline- & - & - & - & .45 & - & - & - & - & - & - & - \\
\hline- & - & .10 & - & -24 & - & - & - & - & - & - & - \\
\hline 61.7 & 52.1 & 74.3 & 69.1 & 74.0 & 67.7 & 65.8 & 44.0 & 70.5 & 50.0 & 51.4 & 55.7 \\
\hline 123 & - & 3.4 & - & 4.5 & 6.6 & - & - & - & - & - & - \\
\hline 5.2 & - & 2.1 & - & 2.2 & 4.9 & $*$ & $*$ & - & - & - & - \\
\hline
\end{tabular}

\begin{tabular}{|c|c|c|c|c|c|c|c|c|c|c|c|}
\hline 5 & 1 & 25 & 16 & 13 & 4 & 6 & 4 & 19 & 4 & 2 & 4 \\
\hline- & - & 23.4 & - & 138 & - & - & - & - & - & - & - \\
\hline
\end{tabular}

\begin{tabular}{|c|c|c|c|c|c|c|c|c|c|c|c|}
\hline- & - & 11.6 & - & 11.2 & - & $*$ & - & - & - & $*$ & - \\
\hline- & - & 15.3 & - & 10.0 & - & $*$ & - & - & - & $*$ & - \\
\hline 4.2 & - & 18.2 & 7.6 & 12.6 & 1.3 & - & - & 12.1 & - & 1.0 & 1.3 \\
\hline 2.2 & - & 8.6 & - & 5.5 & -2.0 & - & - & - & - & - & - \\
\hline 0.5 & - & 3.2 & - & -0.2 & -2.8 & - & - & - & - & - & - \\
\hline- & - & 14.2 & - & 9.4 & - & - & - & - & - & - & - \\
\hline- & - & 39.8 & - & 27.5 & - & - & - & - & - & - & - \\
\hline- & - & 41.8 & - & 33.5 & - & - & $*$ & $*$ & - & - & - \\
\hline- & - & 21.3 & - & 18.3 & - & - & $*$ & - & - & - & - \\
\hline
\end{tabular}




\section{APPENDIX 2}

Nation codes used in plots

\begin{tabular}{|c|c|c|c|}
\hline Albania & $\mathrm{AL}$ & Gabon & GAB \\
\hline Algeria & $\mathrm{DZ}$ & Germany & $\mathrm{D}$ \\
\hline Antigua & ANT & Ghana & $\mathrm{GH}$ \\
\hline Argentina & $\mathrm{RA}$ & Greece & GR \\
\hline Australia & AUS & Grenada & WG \\
\hline Austraia & A & Guuatemala & $\mathrm{GCA}$ \\
\hline Burk.Fasso & $\mathrm{BF}$ & Guinea & GN \\
\hline Bahamas & BS & Guyana & GUY \\
\hline Bahrain & BRN & Haiti & $\mathrm{RH}$ \\
\hline Bangladesh & $\mathrm{BD}$ & Honduras & HND \\
\hline Barbados & $\mathrm{BDS}$ & Hungary & $\mathrm{H}$ \\
\hline Belgium & $\mathrm{B}$ & Iceland & IS \\
\hline Belize & $\mathrm{BH}$ & India & IND \\
\hline Benin & DY & Indonesia & $\mathrm{RI}$ \\
\hline Bolivia & $\mathrm{RB}$ & Iran & IR \\
\hline Brazil & $\mathrm{BR}$ & Iraq & IRQ \\
\hline Bulgaria & $\mathrm{BG}$ & Ireland & IRL \\
\hline Burma & $\mathrm{BU}$ & Israel & IL \\
\hline Burundi & RU & Italy & $I$ \\
\hline C. Africa & RCA & Ivory Coast & $\mathrm{CI}$ \\
\hline Costa Rica & $\mathrm{CR}$ & Jamacia & IA \\
\hline Cameroon & CAM & Japan & $J$ \\
\hline Canada & CDN & Jordan & $\mathrm{HKJ}$ \\
\hline Chad & CHA & Kampuchea & $\mathrm{K}$ \\
\hline Chile & $\mathrm{RCH}$ & Kenya & EAK \\
\hline Colombia & $\mathrm{CO}$ & Kuwait & $\mathrm{KWT}$ \\
\hline Congo & $\mathrm{RCB}$ & Kebanon & $\mathrm{RL}$ \\
\hline Cuba & $\mathrm{C}$ & Liberia & LB \\
\hline Cyprus & $\mathrm{CY}$ & Libya & LAR \\
\hline Czechoslovakia & $\mathrm{CS}$ & Luxemburg & $\mathbb{L}$ \\
\hline Denmark & $\mathrm{DK}$ & Madagascar & $\mathrm{RM}$ \\
\hline Dominican Rep. & Malawi & MW & \\
\hline Ecuador & $\mathrm{EC}$ & Malaysia & MAL \\
\hline Egypt & $\mathrm{ET}$ & Mali & $\mathrm{RMM}$ \\
\hline El Salvador & ES & Malta & $\mathrm{M}$ \\
\hline Ethiopia & ETH & Mauretania & RIM \\
\hline Finland & SF & Mauritius & MS \\
\hline France & $\mathrm{F}$ & Mexico & $\mathrm{MEX}$ \\
\hline
\end{tabular}




$\begin{array}{llll}\text { Morocco } & \text { MA } & \text { Spain } & \text { E } \\ \text { N. Zealand } & \text { NZ } & \text { Sudan } & \text { SUD } \\ \text { Nepal } & \text { NEP } & \text { Surinam } & \text { SME } \\ \text { Netherlands } & \text { NL } & \text { Sweden } & \text { S } \\ \text { Nicaragua } & \text { NIC } & \text { Switzerland } & \text { CH } \\ \text { Niger } & \text { RN } & \text { Syria } & \text { SYR } \\ \text { Nigeria } & \text { WAN } & \text { Tanzania } & \text { EAT } \\ \text { Norway } & \text { N } & \text { Thailand } & \text { T } \\ \text { Pakistan } & \text { PK } & \text { Togo } & \text { TG } \\ \text { Panama } & \text { PA } & \text { Trinidad } & \text { TT } \\ \text { Paraguay } & \text { PY } & \text { Tunisia } & \text { TN } \\ \text { Peru } & \text { PE } & \text { Turkey } & \text { TR } \\ \text { Philippines } & \text { RP } & \text { Uganda } & \text { EAU } \\ \text { Poland } & \text { PL } & \text { United Kingdom } & \text { UK } \\ \text { Portugal } & \text { P } & \text { Urugay } & \text { U } \\ \text { Rumania } & \text { RO } & \text { USA } & \text { USA } \\ \text { Rwanda } & \text { RWA } & \text { Venezuela } & \text { YV } \\ \text { S. Africa } & \text { ZA } & \text { Vietnam } & \text { VN } \\ \text { S. Korea } & \text { ROK } & \text { Yemen } & \text { ADN } \\ \text { Sri Lanka } & \text { CL } & \text { Yugoslavia } & \text { YU } \\ \text { Sierra Leone } & \text { WAL } & \text { Zaire } & \text { ZRE } \\ \text { Senegal } & \text { SN } & \text { Zambia } & \text { Z } \\ \text { Seychelles } & \text { SY } & \text { Zimbabwe } & \text { ZW } \\ \text { Singapore } & \text { SGP } & & \\ \text { Somalia } & \text { SP } & & \end{array}$

